\title{
Sulfides in Biosystems
}

\author{
Mihály Pósfai \\ Department of Earth and Environmental Sciences \\ University of Veszprém \\ Veszprém, Hungary \\ e-mail:posfaim@almos.vein.hu \\ Rafal E. Dunin-Borkowski \\ Department of Materials Science and Metallurgy \\ University of Cambridge \\ Cambridge, United Kingdom
}

\section{INTRODUCTION}

Organisms that live on and near the surface of the Earth affect the cycling of sulfur and metals and thus the formation and decomposition of sulfide minerals. Biological mediation of mineral formation can take many forms. Some organisms have evolved to synthesize minerals that are used for a particular function, such as structural support, protection against predators, hardening, or magnetic sensing. In these cases, the organism exerts strict control over the properties and the location of the mineral. The process by which such minerals form is termed biologically controlled mineralization (BCM) (Lowenstam and Weiner 1989).

Biominerals can also form as a byproduct of the metabolism of organisms, or as a consequence of their mere presence. Life can create chemical environments that result in the precipitation of minerals, and biological surfaces can serve as nucleation sites for mineral grains. In such cases, the adventitious deposition of minerals is termed biologically induced mineralization (BIM) (Lowenstam and Weiner 1989). Whereas only a few examples of the formation of sulfide minerals by BCM are known, iron sulfides form in vast quantities by BIM and affect the global cycling of iron, sulfur, oxygen, and carbon (Canfield et al. 2000; Berner 2001).

Organisms are also able to break minerals down. The dissolution of sulfides can be enhanced by biological processes, while some micro-organisms gain their energy by oxidizing the sulfur or the metal in sulfide minerals, thereby converting sulfides into dissolved species or oxides (Kappler and Straub 2005). The biological mediation of both the precipitation and the dissolution of sulfides can be used for practical purposes, such as bioremediation and bioleaching.

Over the past decade, several reviews have been published on biomineralization, many of which include details on sulfides. In the Reviews in Mineralogy \& Geochemistry series, three volumes have been devoted to interactions between minerals and organisms (Banfield and Nealson 1997; Dove et al. 2003; Banfield et al. 2005). A further short course volume, which includes several chapters on sulfides, was published by the Mineralogical Association of Canada (McIntosh and Groat 1997). A textbook on environmental mineralogy, published by the European Mineralogical Union (Vaughan and Wogelius 2000), also contains material related to biominerals. More recently published general books on BCM include those by Mann (2001) and Baeuerlein (2000, 2004). 
The aim of the present chapter is to discuss some aspects of sulfide biomineralization and sulfide bioweathering. In order to avoid repeating the content of recent reviews, this chapter does not provide a comprehensive treatment of interactions between sulfide minerals and organisms. Instead, its primary focus is a description of the properties of biogenic sulfide minerals that distinguish them from their inorganically-formed counterparts. The relationships between mineral properties and biological functions are discussed, some aspects of sulfide formation by BIM are highlighted, and sulfide bioweathering processes are mentioned briefly. Since iron sulfides are by far the most important and abundant sulfide minerals in biosystems, most of this chapter deals with such minerals.

\section{BIOLOGICAL FUNCTION AND MINERAL PROPERTIES: CONTROLLED MINERALIZATION OF IRON SULFIDES}

Biologically controlled mineralization is a highly regulated process that results in the formation of minerals that have species-specific physical and chemical properties. These properties include size, morphology, structure, crystallographic orientation, composition, and texture. As discussed by Mann (2001), several levels of regulation combine in BCM to provide distinct mineral properties (Table 1). Chemical control through coordinated ion transport is involved in producing supersaturated solutions in spatially separated spaces such as vesicles or gaps in organic frameworks. Organic surfaces play a crucial role in providing nucleation sites and in selecting the phase and orientation of the nucleating mineral (Weiner and Dove 2003). Chemical, spatial, and morphological regulations combine to shape the growing crystals and to assemble them into complex architectures.

Minerals can serve various functions in living organisms. In association with organic materials, they can form inorganic-organic composites that have favorable mechanical properties. Well-known examples include bones that are used for structural support, teeth that are used for grinding, and shells that are used for mechanical strengthening and protection.

Table 1. Processes and mechanisms that control the properties of minerals formed by biologically controlled mineralization, based on concepts that are described by Mann (2001).

\begin{tabular}{|l|l|l|l|}
\hline \multicolumn{1}{|c|}{$\begin{array}{c}\text { Type of } \\
\text { Regulation }\end{array}$} & $\begin{array}{c}\text { Key Factors } \\
\text { of Mineral } \\
\text { Formation that } \\
\text { are Controlled }\end{array}$ & \multicolumn{1}{|c|}{ Means of Control } & \multicolumn{1}{c|}{ Result } \\
\hline Chemical & $\begin{array}{l}\text { Ion concentration } \\
\text { in solution }\end{array}$ & Coordinated ion transport & Supersaturation and nucleation \\
\cline { 2 - 5 } & Crystal growth & Promotors and inhibitors & $\begin{array}{l}\text { - Controlled crystal morphology } \\
\text { - Phase transformations }\end{array}$ \\
\hline Spatial & $\begin{array}{l}\text { Supersaturation and } \\
\text { crystal growth }\end{array}$ & $\begin{array}{l}\text { Vesicles or organic } \\
\text { framework }\end{array}$ & $\begin{array}{l}\text { Controlled location, size and shape } \\
\text { of the mineral }\end{array}$ \\
\hline Structural & $\begin{array}{l}\text { Nucleation } \\
\text { Organic surfaces as } \\
\text { templates, molecular } \\
\text { recognition at organic/ } \\
\text { inorganic interfaces }\end{array}$ & $\begin{array}{l}\text { - Polymorph selection } \\
\text { - Controlled crystallographic } \\
\text { orientation }\end{array}$ \\
\hline $\begin{array}{l}\text { Morphological } \\
\text { constructional }\end{array}$ & $\begin{array}{l}\text { Nucleation and } \\
\text { growth }\end{array}$ & $\begin{array}{l}\text { Organic boundaries, } \\
\text { vectorial regulation }\end{array}$ & $\begin{array}{l}\text { - Complex morphologies } \\
\text { - Time-dependent patterning }\end{array}$ \\
\hline
\end{tabular}


Table 2. Sulfide minerals that are formed by biologically controlled mineralization.

\begin{tabular}{|l|l|l|l|}
\hline \multicolumn{1}{|c|}{ Organism } & \multicolumn{1}{|c|}{ Mineral } & \multicolumn{1}{c|}{ Function } & \multicolumn{1}{c|}{ References } \\
\hline \multirow{4}{*}{$\begin{array}{l}\text { Magnetotactic } \\
\text { bacteria }\end{array}$} & Greigite, $\mathrm{Fe}_{3} \mathrm{~S}_{4}$ & Magnetic sensing & $\begin{array}{l}\text { Farina et al. 1990; } \\
\text { Mann et al. 1990; } \\
\text { Heywood et al. 1990; 1991 }\end{array}$ \\
\cline { 2 - 4 } & Mackinawite, $\mathrm{FeS}$ & Precursor to greigite & Pósfai et al. 1998a,b \\
\cline { 2 - 4 } & $\begin{array}{l}\text { Cubic FeS } \\
\text { (identified tentatively) }\end{array}$ & Precursor to greigite & Pósfai et al. 1998a,b \\
\hline \multirow{3}{*}{$\begin{array}{l}\text { Scaly-foot } \\
\text { gastropod }\end{array}$} & Pyrite, $\mathrm{FeS}_{2}$ & Mechanical protection & $\begin{array}{l}\text { Warén et al. 2003; } \\
\text { Suzuki et al. 2006 }\end{array}$ \\
\cline { 2 - 5 } & Greigite, $\mathrm{Fe}_{3} \mathrm{~S}_{4}$ & Mechanical protection & $\begin{array}{l}\text { Warén et al. 2003; } \\
\text { Suzuki et al. 2006 }\end{array}$ \\
\cline { 2 - 5 } & Mackinawite, FeS & Precursor to greigite & Suzuki et al. 2006 \\
\hline
\end{tabular}

However, the biological uses of minerals are not only mechanical. Biominerals can also serve as optical, magnetic, or gravity sensing devices, and may be used for the storage of materials such as iron (Mann 2001; Baeuerlein 2004).

In contrast to some mineral groups that are common functional materials in many organisms (e.g., carbonates, phosphates, silica), only a few sulfide minerals are known to serve biological functions (Table 2). Although these sulfide minerals include common species such as pyrite $\left(\mathrm{FeS}_{2}\right)$, their formation pathways by $\mathrm{BCM}$ were only discovered in the last 15 years. Greigite $\left(\mathrm{Fe}_{3} \mathrm{~S}_{4}\right)$ is used for magnetic sensing in magnetotactic bacteria (Farina et al. 1990; Mann et al. 1990; Rodgers et al. 1990), and greigite and pyrite both serve as hardening materials on the foot of a deep-sea snail species (Warén et al. 2003; Suzuki et al. 2006). The physical and chemical properties and the apparent functions of these sulfide biominerals are reasonably well known. However, very little is understood about the specific biological control mechanisms that govern crystal nucleation and growth (as listed in Table 1).

\section{Biologically controlled mineralization in magnetotactic bacteria}

Magnetotactic bacteria contain intracellular magnetic iron oxide or sulfide minerals that are typically organized in chains. Such cells are aligned by magnetic fields, and as a result the bacteria are constrained to swim parallel to the direction of the geomagnetic field in their natural aquatic environment (Blakemore 1975). This magnetic alignment mechanism enables the bacteria to find their optimal positions in environments that are characterized by vertical chemical gradients (Frankel et al. 1997). Since geomagnetic field lines are inclined with respect to the surface of the Earth (except at the equator), the bacteria do not have to search for their optimal chemical environment in three dimensions, but are guided up and down along the field lines. Nevertheless, several questions remain about the utility of magnetotaxis; neither the benefit of magnetotaxis at the equator, nor the reason for the presence of south-seeking bacteria in the Northern Hemisphere (Simmons et al. 2005) is fully understood.

The term magnetosome refers to an intracellular magnetic mineral grain enclosed by a biological membrane. Such magnetosome membranes were shown to exist in magnetiteproducing bacteria (Balkwill et al. 1980), and some of the specific membrane proteins and their encoding genes have been identified (Komeili et al. 2004; Schüler 2004; Fukumori 2000). The magnetosome membrane provides spatial, chemical, structural, and morphological regulation (Table 1) of the nucleation and growth of magnetite crystals. The membrane controls the transport of ions into the magnetosome vesicle, a delimited space in which supersaturation 
can be achieved (Fig. 1). It is also likely that the membrane provides the organic template for the oriented nucleation of magnetite crystals (Bazylinski and Frankel 2004). The growth of magnetite crystals is controlled by an unknown mechanism to produce well-defined morphologies. Recently, it was found that magnetite particles are assembled into chains by an acidic membrane protein that anchors the magnetosomes to a filamentous structure (Scheffel et al. 2005) (Fig. 1).

The presence of a magnetosome membrane has never been established in sulfideproducing bacteria. Since such bacteria are not yet available in pure culture, it is difficult to determine whether the iron sulfide crystals are enclosed by membranes that are similar to those in magnetite-producing cells. Little is therefore known about the biological regulation of mineral formation in sulfide-bearing bacteria. However, the properties of the inorganic sulfide phases themselves are fairly well understood. These properties can provide indirect information about the mineral-forming process.

The biomineralization of magnetite and sulfides by magnetotactic bacteria, including their micro- and molecular biology and ecology, has been reviewed by Bazylinski and Moskowitz (1997), Baeuerlein (2003), and Bazylinski and Frankel (2003, 2004). Some of the mineralogical aspects of sulfide formation in magnetotactic bacteria are now described, and recent measurements of the magnetic microstructures of chains of greigite magnetosomes in magnetotactic cells are reviewed.

\section{Sulfide-producing magnetotactic bacteria}

Sulfide-producing magnetotactic organisms are known to exist in anaerobic marine environments, saltwater ponds, and sulfur-rich marshes (Farina et al. 1990; Mann et al. 1990; Bazylinski and Frankel 2004). The cell morphologies of sulfide-bearing magnetotactic bacteria appear to be very similar in geographically distant locations (Farina et al. 1990; Mann et al. 1990; Bazylinski et al. 1990; Pósfai et al. 1998b; Simmons et al. 2004). One organism is termed the many-celled magnetotactic prokaryote (Rodgers et al. 1990), or alternatively

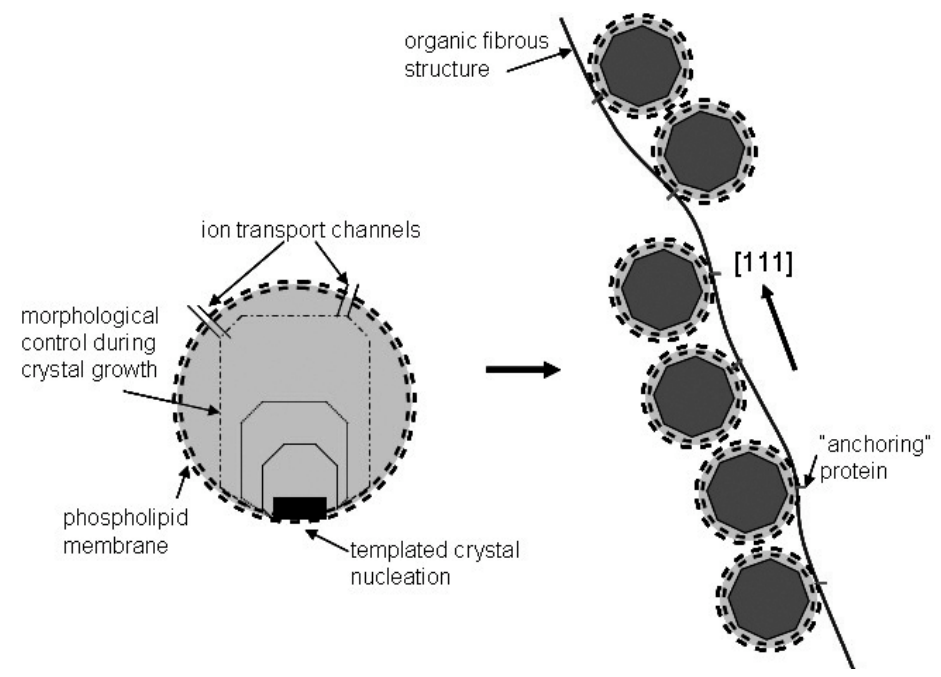

Figure 1. Stages of biologically controlled mineralization in magnetotactic bacteria, as known in the case of magnetite-producing cells. Iron sulfide-producing species may use similar strategies for mineralizaton. The inorganic crystal nucleates and grows inside a magnetosome vesicle, and then the magnetosomes are attached to a filamentous structure by an acidic protein. (Based largely on the model by Scheffel et al. 2005.) 

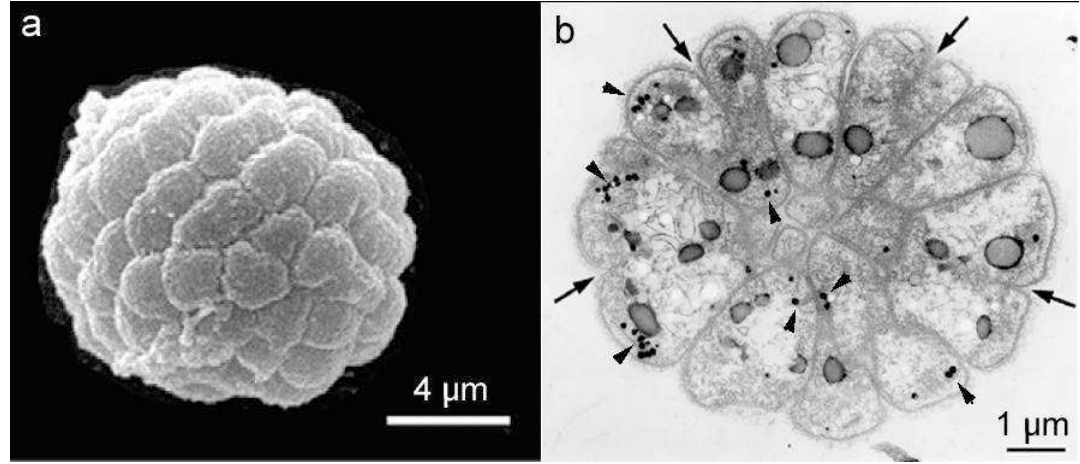

Figure 2. (a) SEM image of the magnetotactic multicellular aggregate (MMA) that consists of many cells and moves as a single unit. (b) Ultrathin section of an MMA. The arrows mark invaginations of the cell wall, indicating the sites of cell division, and the arrowheads mark iron sulfide magnetosomes. [Used with permission of Elsevier, from Keim et al. (2004) J. Structural Biology, Vol. 145, Figs. 3c and 5, p. 254-262.]

the magnetotactic multicellular aggregate (MMA) (Lins and Farina 1999). This organism consists of an aggregate of 10 to 30 cells that are arranged in an ordered fashion, enclosing an acellular internal compartment. Each cell contains one or more chains of greigite crystals, which are aligned approximately parallel to each other within the individual cells (Keim et al. 2004) (Fig. 2). The MMA moves as a single unit, guided by Earth's magnetic field. Other common morphological types include rod-shaped cells that may contain single or multiple chains of iron sulfide crystals (Heywood et al. 1991; Bazylinski et al. 1995) (Fig. 3). Although attempts to cultivate sulfide-producing magnetotactic bacteria in pure culture have to date been unsuccessful, fluorescent in situ hybridization studies

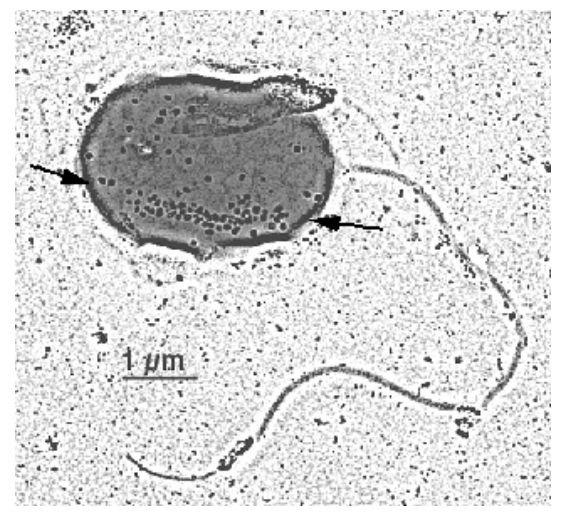

Figure 3. A single, rod-shaped magnetotactic cell that contains a double chain of iron sulfide magnetosomes between the two arrows. (Image from Kasama et al. 2006.) indicated that the MMA is closely related to known sulfate reducers among the $\delta$-proteobacteria (DeLong et al. 1993), whereas a large rod was found to be a member of the $\gamma$-proteobacteria and is likely involved in metal cycling (Simmons et al. 2004).

Sulfide-bearing magnetotactic bacteria live below the oxic-anoxic transition zone (OATZ), where $\mathrm{H}_{2} \mathrm{~S}$ is abundant (Bazylinski and Frankel 2004). MMAs and rod-shaped cells have been observed in distinct zones below the OATZ in Salt Pond, Massachusetts, USA (Simmons et al. 2004). Whereas the concentration of MMAs was largest just below the OATZ, rod-shaped cells appeared to be broadly distributed vertically in a zone that was characterized by the absence of dissolved oxygen and by a high $\mathrm{H}_{2} \mathrm{~S}$ concentration (Fig. 4). In such an environment, the benefit of possessing an internal compass is unclear. It was speculated that intracellular iron sulfide (and oxide) crystals could serve purposes other than magnetically-assisted navigation (Simmons et al. 2004; Flies et al. 2005). In addition, populations of south-seeking magnetotactic bacteria were recently observed in the Northern Hemisphere (Simmons et al. 2006), challenging the widely-held view about the utility of magnetic navigation for these mi- 


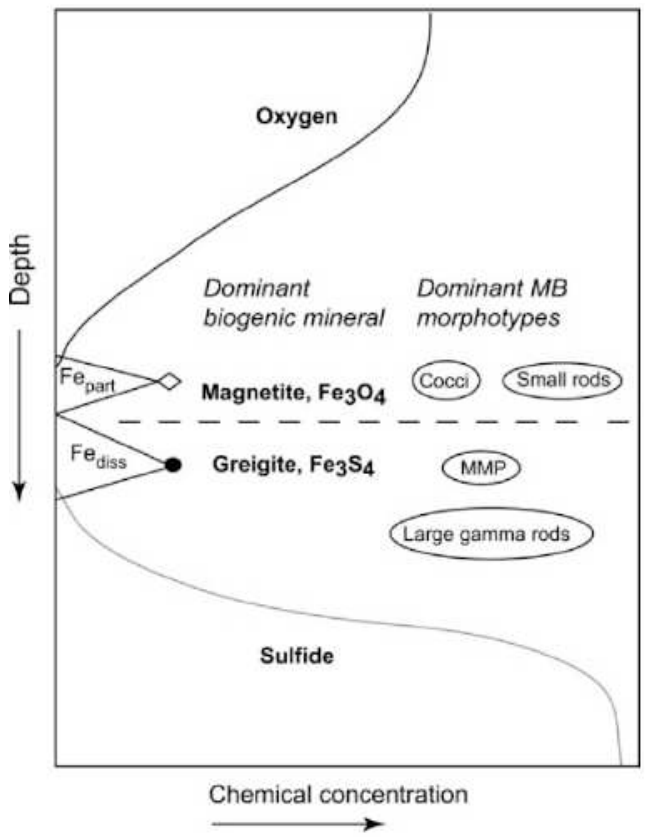

Figure 4. The positions of the types of magnetotactic bacteria $(\mathrm{MB})$ in the water column of Salt Pond, Massachusetts, with respect to depth and the concentrations of oxygen and sulfide. Magnetite-bearing cocci and small rods predominate at the oxic-anoxic transition zone, whereas iron sulfide-bearing magnetotactic multicellular prokaryotes (MMP) and large gamma rods predominate below it. Peaks in the concentrations of particulate and dissolved iron ( $\mathrm{Fe}_{\text {part }}$ and $\mathrm{Fe}_{\text {diss }}$, respectively) are also shown. [Used with permission of American Society for Microbiology, from Simmons et al. (2004), Applied and Environmental Microbiology, Vol. 10, Fig. 7, p. 6230-6239.]

cro-organisms. Further studies on the physiology and ecology of magnetotactic bacteria will be required in order to establish whether the synthesis and presence of magnetosomes serve purposes other than magnetic sensing.

\section{Structures and compositions of iron sulfide magnetosomes}

The inorganic part of each iron sulfide magnetosome is typically a crystal of greigite. However, in freshly-collected cells (a few days old), mackinawite (FeS) was identified (Pósfai et al. 1998a). When the samples were stored in air, mackinawite was observed to convert into greigite. This observation suggests that non-magnetic mackinawite precipitates initially, and then converts into magnetic greigite through the loss of $1 / 4$ of its iron. Disordered crystals may represent transitional states between the mackinawite and greigite structures and suggest that the transformation takes place in the solid state. Structural similarities between the cubic closepacked sulfur substructures of mackinawite and greigite would allow such a conversion to take place by the diffusion of iron atoms, leaving the sulfur atomic arrangement intact (Fig. 5).

The transformation that was observed in the stored specimens is also thought to take place within living bacteria. The transformation is likely to be faster in living bacteria than in the stored samples, since non-magnetic mackinawite cannot be used for magnetotaxis. In addition to mackinawite, cubic FeS with a sphalerite-type structure was identified tentatively in some magnetotactic cells, based on electron diffraction patterns (Pósfai et al. 1998a). Since this initial identification of cubic FeS, several further attempts to confirm its presence have been unsuccessful. It remains to be established unequivocally that cubic $\mathrm{FeS}$ is also a precursor of greigite in magnetotactic bacteria.

The conversions of iron sulfides in bacteria follow similar paths as the well-known phase transformations of authigenic sulfides that form by BIM in anoxic sediments (see Luther and Rickard, 2006; this volume, and the section below on BIM sulfides). However, in marine sediments the final product of iron sulfide formation is commonly pyrite instead of greigite (Schoo- 


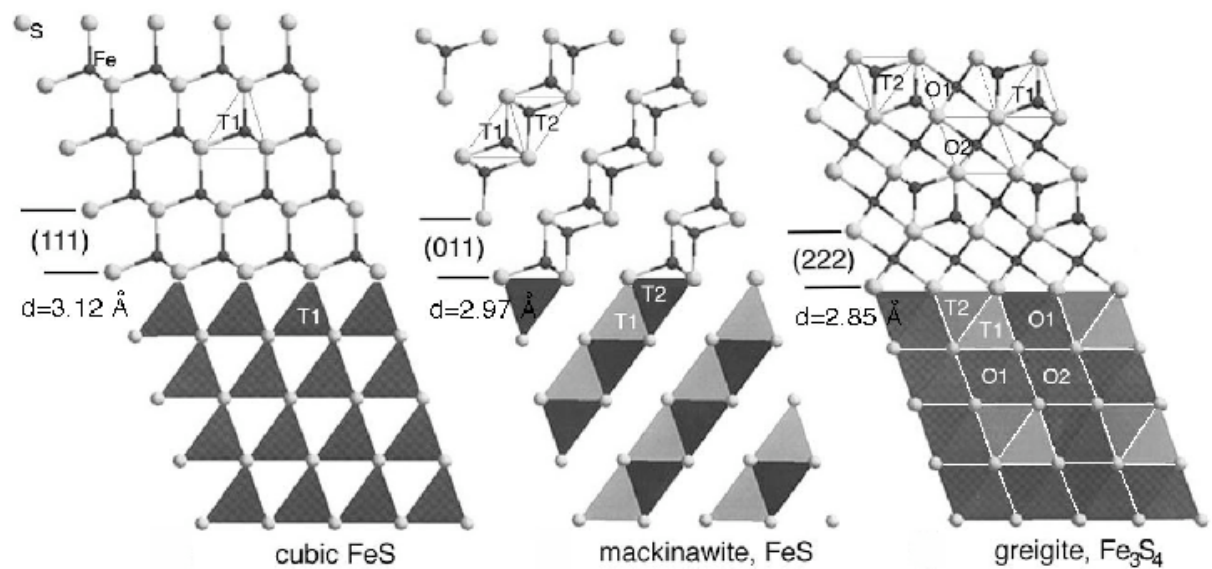

Figure 5. The structural relationships among cubic FeS, mackinawite, and greigite. Light and dark circles represent sulfur and iron atoms, respectively. The lower half of the image shows the same structures in polyhedral respresentation. T1 and T2 mark tetrahedral, and $\mathrm{O} 1$ and $\mathrm{O} 2$ mark octahedral positions. (Figure from Pósfai et al. 1998b.)

nen 2004). Rickard et al. (2001) found that mackinawite converts to either greigite or pyrite, depending on the presence or absence of carboxylic aldehydes in the solution, respectively. Even though the organic compound was present in very low concentration, it served as a switch that determined the mineral phase. Similar molecular switches have not yet been identified in magnetotactic bacteria, but the concept of a chemical control mechanism over the selection of the mineral phase is consistent with the principles of BCM that are outlined in Table 1.

Greigite magnetosomes typically exhibit patchy contrast in transmission electron microscope (TEM) images (Heywood et al. 1990; Pósfai et al. 1998b). This appearance may be related to the presence of defects that arise from the solid-state transformation of mackinawite into greigite. It may also result from thickness variations. High-resolution TEM images provide evidence that many greigite magnetosomes are aggregates of smaller, flake-like fragments that combine to form a single crystal (Kasama et al. 2006), and that such aggregates can have highly irregular shapes. Synthetic mackinawite was found to precipitate in the form of plate-like nanocrystals with an average size of a few nm (Wolthers et al. 2003; Ohfuji and Rickard 2006). The formation of primary mackinawite in magnetotactic bacteria by a similar mechanism, through the nucleation and aggregation of plate-like nanocrystals, cannot be ruled out.

Although greigite magnetosomes are typically pure iron sulfides, in some samples copper was found to substitute for iron by up to 12 at\% (Bazylinski et al. 1993a; Pósfai et al. 1998b). The copper content appeared to be independent of cell type, but was related to geographical location, and therefore presumably to the copper concentration in the environment of the bacteria. When the samples of greigite-containing bacteria are stored in air, the greigite crystals oxidize partially, and an amorphous iron oxide shell forms on them (Lins and Farina 2001; Kasama et al. 2006) (Fig. 6). This phenomenon was observed to reduce the magnetic moments of the magnetosomes (Kasama et al. 2006).

\section{Magnetic sensing with sulfide magnetosomes}

Magnetotactic bacteria are the only organisms that are known to make use of the magnetic properties of iron sulfide crystals for navigation. Other organisms that navigate magnetically include algae, protists, bees, ants, fishes, turtles, and birds (Wiltschko and Wiltschko 1995; 


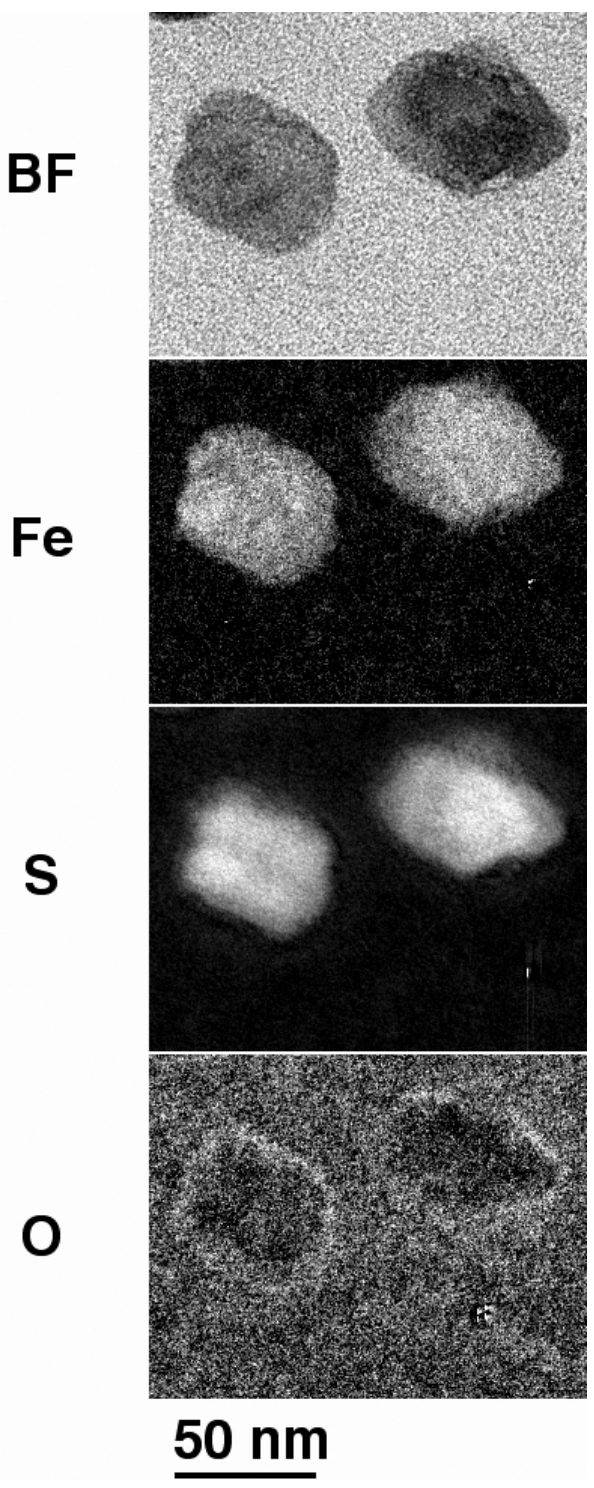

Figure 6. Three-window, background-subtracted elemental maps of two iron sulfide magnetosomes from a magnetotactic bacterium. BF: bright-field image; the images marked $\mathrm{Fe}, \mathrm{S}$, and $\mathrm{O}$ show the distributions of the respective elements. The magnetosomes have a crystalline iron sulfide core and an amorphous iron oxide shell.
Walker et al. 2002). In the few cases for which the mechanism of magnetic sensing is known, the mineral involved is magnetite (Kirschvink et al. 2001; Winklhofer et al. 2001; Diebel et al. 2000). Magnetite also occurs in the human brain (Kirschvink et al. 1992; Dobson 2001), but it remains to be established whether it has a biological function.

Magnetosomes in magnetotactic bacteria are typically arranged in chains, with each chain behaving as a magnetic dipole (Frankel 1984). The Earth's magnetic field exerts a torque on this dipole, and competes with the effect of Brownian motion that tends to randomize the orientation of the cell. When the magnetic moment of a cell is known, its average orientation with respect to the external magnetic field can be calculated on the basis of the Langevin function, as discussed in detail by Bazylinski and Moskowitz (1997). Both calculations and experiments show that magnetite-producing bacteria typically contain enough magnetosomes to allow their cells to migrate parallel to the small $(50 \mu \mathrm{T})$ magnetic field of the Earth with a net velocity that is in excess of $90 \%$ of their forward velocity (Frankel 1984; Schüler et al. 1995). Since the magnetic induction of greigite $(0.16 \mathrm{~T})$ is only about one quarter of that of magnetite (0.60 T) (Dunlop and Özdemir 1997), a cell needs a larger number of greigite than magnetite crystals (of similar size) in order to be magnetotactic (Heywood et al. 1991).

The mechanism of magnetic alignment described above requires the magnetosome crystals to be magnetized approximately parallel to each other at room temperature. The combined effects of their shape and magnetocrystalline anisotropy, as well as interparticle interactions between magnetosomes, determine the magnetic domain state, and therefore the net magnetic dipole moment, of each magnetosome. Based on theoretical considerations, Diaz-Ricci and Kirschvink (1992) calculated the size and shape-dependent magnetic properties of greigite, and determined that the sizes of bacterial magnetosomes place them at the boundary between the superparamagnetic and single magnetic domain size range for isolated crystals. They also reported that crystal shape affects the magnetic properties of greigite significantly. Whereas isolated $\sim 70-\mathrm{nm}$ crystals with prismatic habits 
were calculated to be single domains, spheroidal particles of similar size were superparamagnetic at room temperature. Experimental results obtained by Chen et al. (2005) also indicate that the magnetic properties of acicular and irregularly-shaped greigite nanocrystals differ.

Measurements of the magnetic properties of greigite-producing magnetotactic bacteria are scarce. As a result of the present inability to grow sulfide-producing magnetotactic organisms in pure culture, it has not been possible to apply bulk magnetic characterization techniques to their study. Recently, Kasama et al. (2006) used off-axis electron holography in the TEM to study the magnetic properties of greigite magnetosomes in rod-shaped cells. Electron holography is a powerful and relatively specialized technique that can be applied to the study of magnetic and electrostatic fields in materials (Dunin-Borkowski et al. 2004). By using electron holography, it is possible to measure parameters such as the magnetic moments and coercivities of individual magnetosomes and their chains quantitatively, as well as to form two-dimensional images of the projected magnetic induction (Dunin-Borkowski et al. 1998, 2001).

The magnetic properties of sulfide magnetosomes were studied in a cell that was at the point of division (Fig. 7a) (Kasama et al. 2006). The structures of some of the magnetosomes in this cell were studied using selected-area electron diffraction and high-resolution TEM, their compositions were determined using energy-filtered TEM, and their three-dimensional morphologies were studied using high-angle annular dark-field electron tomography. The electron holography experiments revealed that the direction of the magnetic field is less uniform within the magnetosome chains, and undulates to a greater degree than in magnetitecontaining cells. In addition, some of the greigite crystals (marked by arrows in Fig. 7b) appeared to be only weakly magnetic, with the apparent saturation magnetic induction varying between 0 and $0.16 \mathrm{~T}$ for individual crystals in the cell. This behavior could result either from the presence of non-magnetic sulfides other than greigite, or from the fact that some of the greigite crystals may be magnetized in a direction that is almost parallel to that of the electron beam. Since electron holograms are only sensitive to the components of the magnetic field in the plane of the specimen, i.e., perpendicular to the electron beam direction, magnetic crystals with large out-of-plane components of their magnetization would appear to be non-magnetic. Diffraction patterns obtained from several of the apparently non-magnetic crystals were found to be consistent with greigite. The diffraction patterns also showed that the greigite crystals were oriented randomly within the cell, and that their elongation directions appeared to be random. The variable degree of the apparent magnetization of the greigite magnetosomes is therefore likely to be primarily a consequence of their random orientations. Figure $7 \mathrm{~b}$ also reveals that the magnetic contours within individual crystals are generally parallel to their axes of elongation. These observations are consistent with the calculations of Diaz-Ricci and Kirschvink (1992) that suggest that shape anisotropy has a much larger effect on the magnetization of greigite than magnetocrystalline anisotropy.

Interestingly, the multiple magnetosome chain shown in Figure $7 \mathrm{~b}$ contains magnetite crystals in addition to the greigite magnetosomes (Kasama et al. 2006). Whereas the greigite grains are equidimensional or only slightly elongated, the iron oxide particles have distinctly elongated shapes, and their axes of elongation are aligned parallel to that of the magnetosome chain (Fig. 7c). Their elongated morphologies constrain their magnetic contours to be parallel to the chain axis (Fig. 7d). In addition, since magnetite is much more strongly magnetic than greigite, the magnetite particles contribute as much as $\sim 30 \%$ of the total magnetic moment of the chain, which was measured by electron holography to be $1.8 \times 10^{-15} \mathrm{Am}^{2}$. Whereas the randomly-oriented greigite particles produce an undulating magnetic field, the well-aligned magnetite particles provide a distinct "magnetic backbone" to the chain (Fig. 7d). The presence of both greigite and magnetite magnetosomes in the same cells was reported previously by Bazylinski et al. (1993b). The distinct shapes and orientations of these two mineral species suggest that their formation may be regulated by different biological mechanisms. 

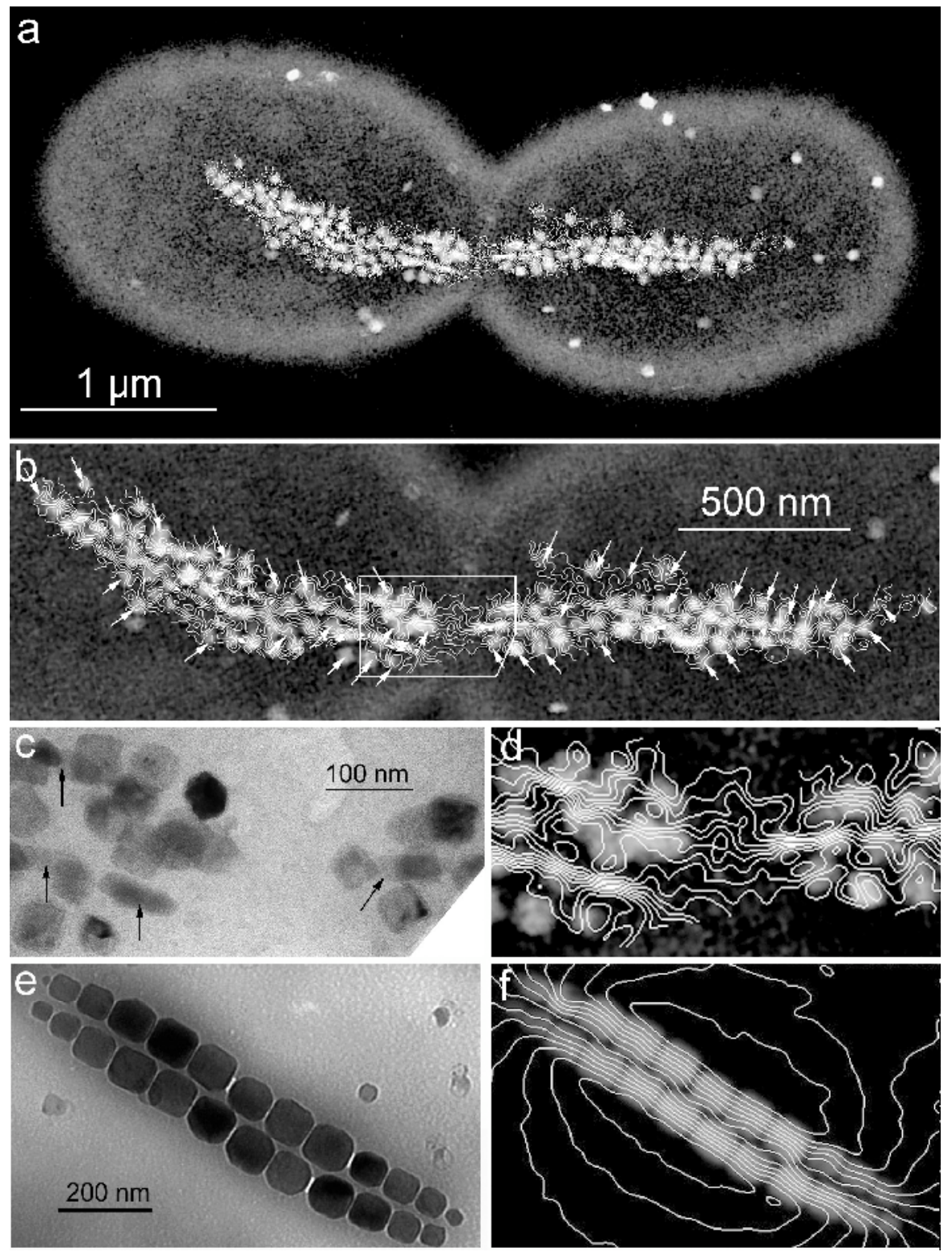

Figure 7. (a) Compositional map of a rod-shaped cell that contains iron sulfide magnetosomes. The cell was caught at the point of cell division. The image was constructed from electron energy-loss maps. (b) Magnetic induction map of the magnetosome chain in (a), obtained from electron holography. The magnitude and the direction of magnetic induction within the crystals is represented by the density and direction of the contour lines, respectively. The arrowed particles appear to be either non-magnetic or weakly magnetic. (c) Bright-field TEM image of the boxed region in (b). The arrowed particles are elongated magnetite crystals. (d) Magnetic induction map from the same area that is shown in (c). The density of the contour lines is much higher in the elongated magnetite crystals than in the equidimensional greigite crystals. (e) Brightfield image and (f) magnetic induction map obtained from a double magnetite chain from a magnetotactic coccus. In contrast to the greigite chain in (b), the magnetic contour lines are straight and their densities uniform within the particles in (f). [Based on images from Kasama et al. 2006.] 
As mentioned above, the biological regulation of the nucleation and growth of magnetosomes has only been studied in magnetite-producing bacteria. The use of analogies with magnetite formation to explain control over greigite deposition in bacteria appears to be limited, because there are significant differences between the properties of sulfide and oxide magnetosomes. Some of these differences are illustrated in Figure 7f, which shows a magnetic contour map of a double magnetite chain in a cell of a magnetotactic coccus. The magnetite crystals in this cell have identical morphologies along the entire chain (Fig. 7e), and their [111] axes are aligned with the magnetosome chain within a few degrees, resulting in the same direction of magnetic induction in each crystal (Simpson et al. 2005a). In contrast, the dividing cell in Figure 7a appears to exhibit a lack of control over the shapes and orientations of the greigite crystals. As a result, the magnetic induction is highly variable along the magnetosome chain. The bacterium appears to compensate for the magnetically less efficient assembly of magnetosomes, as well as for the lower magnetization of greigite than magnetite, by forming a multiple chain that contains several times as many crystals as the magnetite chain shown in Figure 7e.

Not only the processes of crystal nuclation and growth, but also the mechanisms of chain assembly appear to be different in the magnetite and greigite producers. Whereas magnetite particles in magnetotactic spirilla were found to be aligned along a filament that runs along the long axis of the cell (Scheffel et al. 2005; Komeili et al. 2006), electron tomography experiments on the dividing cell shown in Figure 7a revealed a three-dimensional arrangement of the crystals in the multiple greigite chain (Kasama et al. 2006).

To date, the magnetic moments of magnetosome chains in three different strains of magnetite-producing bacteria (MS-1 and MV-1, Dunin-Borkowski et al. 1998, 2001; Itaipu1, McCartney et al. 2001) and in two cells of unnamed sulfide producers (Kasama et al. 2006) have been measured experimentally using electron holography. Remarkably, in the different types of cell the magnetic moments per cell are all the same to within a factor of two. Therefore, even though the biomineralization processes and the properties of magnetosomes may vary between different groups of magnetotactic bacteria, natural selection appears to have favored structures that serve the function of magnetic sensing equally well.

\section{Mechanical protection: iron sulfides on the foot of a deep-sea snail}

Hydrothermal vents in mid-ocean ridge systems provide chemical energy for diverse populations of chemoautotrophic bacteria (as reviewed by Jannasch and Mottl 1985). The abundance of micro-organisms at deep-sea vents makes it possible for more complex organisms (such as worms, shrimp, crabs, clams, mussels, gastropods, anemones, barnacles, etc.) to thrive in an environment where no light is available. Thus, entire ecosystems depend on geochemical rather than on solar energy. Based on variations in the species composition of invertebrate communities, faunas at oceanic vents are recognized to belong to six provinces (Van Dover et al. 2001). One of these provinces is the central ridge system in the Indian Ocean, where, among many other animals, the vent fields harbor a snail that bears mineralized scales on its foot (Van Dover et al. 2001).

The sides of this gastropod's foot are covered in a tile-like fashion by black sclerites (Fig. 8). The scales consist of iron sulfide minerals (Warén et al. 2003), making this snail the first known organism that uses sulfide minerals for structural support. Initially, greigite and pyrite were described as the primary mineral phases (Warén et al. 2003; Goffredi et al. 2004), but mackinawite was also subsequently identified (Suzuki et al. 2006). The presence of greigite makes the scales magnetic. As Suzuki et al. (2006) note, "it is rare for animals to produce macroscopic materials that stick to a hand magnet." The only other known organisms that produce such structures are chiton mollusks that have magnetite-bearing radular teeth (Lowenstam 1962).

The spatial distributions, microstructures, magnetic and mechanical properties, and the isotopic compositions of the iron sulfide minerals in this organism were studied by Suzuki 
et al. (2006). The sulfides were found to be present in three distinct layers, which were defined both by their positions and by their mineral species. An "iron sulfide" layer covers the outer surface of the sclerites and consists primarily of greigite. A "mixed layer" and a "conchiolin layer" occur within the organic matrix, and consist of nanocrystalline pyrite and mackinawite, respectively (Fig. 9). The greigite crystals in the iron sulfide layer are rod-shaped and highly elongated along [110], with average lengths and widths of 118 and $14 \mathrm{~nm}$, respectively. The space between the greigite rods is filled by fibrous mackinawite (Fig. 10). The orientation relationship between the two phases appears to be the same as that described above for sulfides in magnetotactic bacteria, although the boundary plane is different. The pyrite in the mixed layer has an unusual appearance, since it takes the form of nanoparticles that are as small as $3 \mathrm{~nm}$. Remarkably, the nanoparticles have a consistent crystallographic orientation. In the conchiolin layer, mackinawite forms $\sim 3-10 \mathrm{~nm}$ particles within amorphous iron sulfide.

The complex composite of three iron sulfide minerals and organic material results

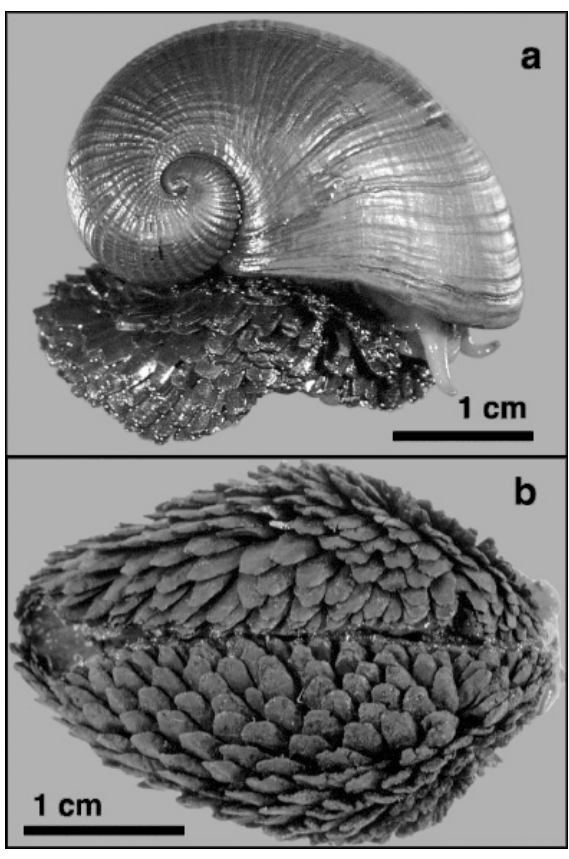

Figure 8. Two views of the "scaly-foot gastropod" that has iron sulfide sclerites on its foot. [Used by permission of Elsevier, from Suzuki et al. (2006), Earth and Planetary Science Letters, Vol. 242, Fig. 1, p. 40.] in interesting magnetic and mechanical properties. The presence of ferrimagnetic greigite raises the question of whether the snail uses this mineral for magnetic sensing. Bulk magnetic measurements reveal that most of the greigite crystals are single magnetic domains, but a significant fraction of superparamagnetic greigite is also present (Suzuki et al. 2006). Measurements of anhysteretic remanent magnetization indicate strong interparticle interactions. In addition, the ratio of natural remanent magnetization to isothermal remanent magnetization is consistent with the presence of random orientations of the greigite crystals. All of these observations suggest that the properties of the greigite crystals are not optimized for magnetic sensing, and that the snail does not use the greigite crystals as a magnetic compass (Suzuki et al. 2006).

The mechanical properties of the biomineralized layers are consistent with a hardening function. Nanoindentation studies show that the iron sulfide layer is harder and stiffer than human enamel, and stiffer than molluscan shell nacre (Suzuki et al. 2006). Whereas the minerals provide rigidity, the associated organic material provides toughness. Since the scalyfoot gastropod shares its habitat at the base of black smoker chimneys with predators such as brachyurean crabs (Suzuki et al. 2006) and other gastropods (Warén et al. 2003), it is likely that the hard and tough iron sulfide/organic composite is used for protection.

There is some ambiguity about whether the snail controls the deposition of the sequence of iron sulfide minerals. The iron sulfide layer is known to be covered by bacteria where it is overlain by adjacent sclerites (Warén et al. 2003). The phylogenetic affiliations of these episymbiotic bacteria have been studied by Goffredi et al. (2004), who found a predominance of bacteria belonging to lineages that are involved in sulfur cycling. Similar bacteria were not 


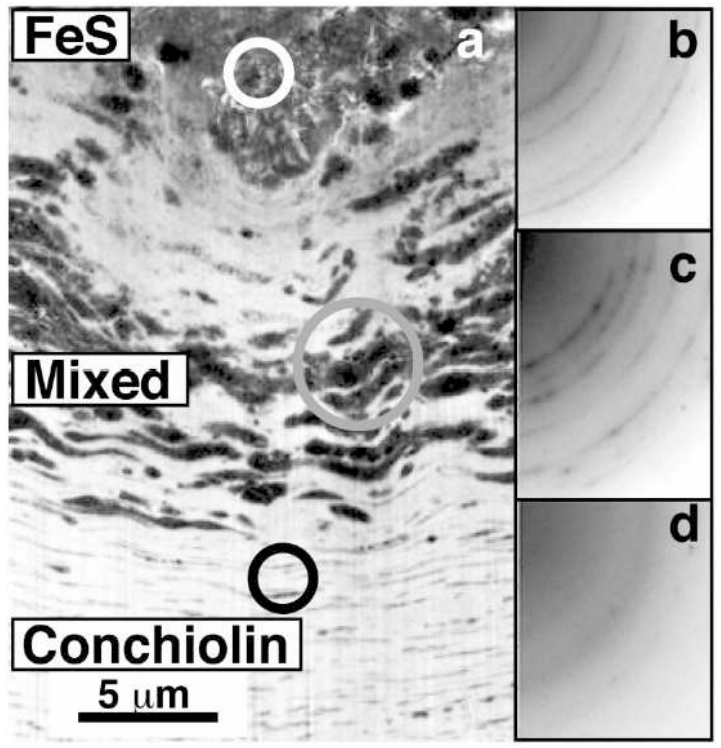

Figure 9. TEM image (a) of a cross-section of the sclerite of the scaly-foot gastropod. Selected-area electron diffraction patterns $(b, c, d)$ obtained from the circled regions in a), indicating (b) greigite from the FeS layer, (c) pyrite from the mixed layer, and (d) mackinawite from the conchiolin layer. [Used by permission of Elseveir, from Suzuki et al. (2006), Earth and Planetary Science Letters, Vol. 242, Fig. 2, p. 42.]

Figure 10. (a) TEM image of rod-shaped crystals from the iron sulfide layer of the sclerite of the scaly-foot gastropod, and (b) electron diffraction pattern from one of the crystals, indicating that it is greigite. The fibrous material next to the rods consists of mackinawite. [Used by permission of Elseveir, from Suzuki et al. (2006), Earth and Planetary Science Letters, Vol. 242 Fig. 3, p. 43.]

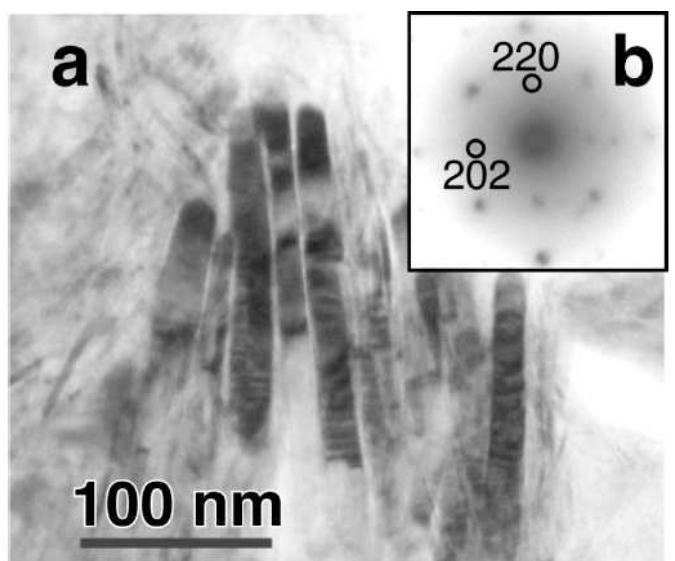

found on other available surfaces or among other gastropods within the same habitat. These observations prompted Goffredi et al. (2004) to speculate that iron sulfide mineralization is a consequence of the metabolism of these symbiotic bacteria. If sulfate-reducing bacteria were the source of sulfur for the sclerites, then a significant enrichment of light isotopes would be expected. However, Suzuki et al. (2006) measured the isotopic compositions of iron and sulfur and found the values to be close to those of the sulfide and iron in the hydrothermallydeposited chimneys. Thus, hydrothermal fluids appear to be a more likely source than episymbiotic bacteria of the iron and sulfur that are involved in sclerite mineralization. The presence of iron sulfides within the conchiolin tissue may also indicate the involvement of the snail in the precipitation of sulfide minerals.

Sulfide mineralization by the scaly-foot snail is the first known case of pyrite formation by BCM. The sulfide mineral assemblage in this organism is also unique in terms of its macroscopically magnetic character and its structural role. Although greigite and mackinawite 
form in both magnetotactic bacteria and the scaly-foot snail, some of their physical properties and their biological functions are different in the two cases. Much research is still needed to understand the biological control of the deposition of iron sulfides in both types of organisms.

\section{BIOLOGICALLY INDUCED FORMATION OF SULFIDE MINERALS}

Biologically induced mineralization is usually considered to be an uncontrolled consequence of metabolic activity, which produces minerals that are characterized by poor crystallinity, a broad particle size distribution, and a lack of well-defined crystal morphology and chemical purity (Frankel and Bazylinski 2003). If the metabolic products diffuse away from the micro-organism, and if the mineral-forming reactions take place in solution or on sediment particles, then the precipitated products may be indistinguishable from minerals that form by purely inorganic processes. However, in many cases bacterial surfaces or extracellular polymeric materials act as passive or active nucleation sites (Fortin et al. 1997; Schultze-Lam et al. 1996; Fortin and Langley 2005). In such cases, the biological material plays a direct role in crystal nucleation, and the minerals that form may have species-specific physical or chemical properties. Thus, BIM encompasses a broad range of mineral-forming processes, many of which are unique to the particular minerals or organisms that are involved in their formation.

Many common sulfide minerals can form by BIM, but the precipitation of iron sulfides is geologically the most important and the most extensively studied problem. Recently, Rickard and Morse (2005) provided a critical review of research into iron sulfide formation, including an assessment of the "myths and facts" that have accumulated over the past 40 years. Sedimentary pyrite formation has also been reviewed by Schoonen (2004), and aspects of the formation of sulfides by BIM are discussed in this volume by Rickard and Luther (2006). Here, the key processes that are involved in BIM are described, including a brief discussion of iron sulfide formation and a review of interesting examples of zinc sulfide mineralization.

\section{Microbial sulfate and metal reduction}

The activity of dissimilatory sulfate-reducing prokaryotes (SRP), which supplies reactive sulfide ions, is key to the formation of sulfide minerals by BIM (Frankel and Bazylinski 2003). Bacteria inhabit distinct redox zones according to their physiology (as reviewed in several textbooks of mineralogy and geochemistry, e.g., Nealson and Stahl 1997; Gould et al. 1997; Aplin 2000). Micro-organisms oxidize carbon in organic matter, using a variety of terminal electron acceptors, ranging from $\mathrm{O}_{2}$ under aerobic conditions to $\mathrm{SO}_{4}{ }^{2-}$ in anoxic environments.

SRP represent a morphologically and phylogenetically heterogeneous group. They are generally strict anaerobes that oxidize simple organic compounds or hydrogen using sulfate ions, as shown for example by the reaction (Tuttle et al. 1969):

$$
2 \mathrm{CH}_{2} \mathrm{O}+\mathrm{SO}_{4}{ }^{2-} \rightarrow 2 \mathrm{HCO}_{3}{ }^{-}+\mathrm{H}_{2} \mathrm{~S}
$$

In this process, the sulfur in the sulfate ion is reduced completely to sulfide, which is released into the environment. Whereas a considerable proportion of the reactive sulfide diffuses upwards and is reoxidized (Jørgensen 1977), part of it combines with metals (primarily iron) to form sulfide minerals (Berner 1970).

Since SRP can use relatively small organic molecules as electron donors, they generally depend on other microbial populations that degrade complex organic compounds. Two major groups of SRP exist, one that incompletely oxidizes organic substrates into acetate (e.g., Desulfovibrio, Desulfotomaculum, Desulfomonas, Desulfobulbus), and another that completely oxidizes organic matter to $\mathrm{CO}_{2}$ (e.g., Desulfococcus, Desulfosarcina, Desulfonema) (Gould et al. 1997). Some hyperthermophilic archaea are also dissimilatory sulfate reducers. SRP are ubiquitous in many anaerobic environments, including lakes, swamps, soils, waste ponds, 
hydrothermal systems, and even within the lithosphere (Lovley and Chapelle 1995). In terms of the amount of sulfide mineralization and its global biogeochemical effect, SRP that occur in marine sediments are most important (Schoonen 2004).

In addition to sulfate reduction, the microbial reduction of metals (such as iron and manganese) is also important in biogenic sulfide mineralization, since it may contribute to the pool of metal ions that are available for mineral formation (Rickard and Morse 2005). Dissimilatory iron-reducing prokaryotes were shown to respire using ferric iron in minerals, and to exert a strong influence on the geochemistry of many environments (Nealson and Saffarini 1994; Methe et al. 2003). Iron reducers are phylogenetically diverse, and include several genera of bacteria (such as Geobacter and Shewanella) and even archaea (Kappler and Straub 2005). Many of these organisms are phylogenetically closely related to SRP, and include species that can also reduce elemental sulfur. Iron-reducing microorganisms can even use iron from relatively poorly reactive minerals such as magnetite and sheet silicates. The potential role of such micro-organisms in dissolving iron and indirectly affecting the sulfur cycle in sediments is only now beginning to be appreciated (Rickard and Morse 2005).

\section{The role of biological surfaces in mineral nucleation}

In general, the heterogeneous nucleation of biominerals is favored kinetically over homogeneous nucleation. Biological surfaces provide excellent nucleation sites for a number of minerals, including sulfides. The properties of different types of mineral-nucleating biological surfaces were reviewed by Schultze-Lam et al. (1996), Fortin et al. (1997), Konhauser (1998), Frankel and Bazylinski (2003), and Gilbert et al. (2005).

The outer surfaces of bacterial cell walls are predominantly negatively charged at near neutral $\mathrm{pH}$, irrespective of whether they belong to gram-positive or gram-negative structural types (Fortin et al. 1997). Therefore, they attract positive ions from solution and thereby initiate the nucleation of metal sulfides. In natural environments, additional biological layers exist on the cell walls. These layers include capsules that usually consist of acidic polysaccharides, Slayers that consist of regular arrays of proteins (Beveridge 1989), sheaths, stalks, and filaments (Gilbert et al. 2005). Many of these surfaces are known to induce the nucleation of metal oxides and sulfides (Fortin et al. 1997; Gilbert et al. 2005).

The ability of bacterial surfaces to bind metal ions is related to the presence of acidic functional groups. As discussed by Gilbert et al. (2005), proteins or polysaccharides that are rich in negatively charged carboxyl $\left(\mathrm{COO}^{-}\right)$groups are the most common and effective cationbinding macromolecules in biomineral nucleation. A general sorption reaction for a metal cation $M$ of charge $z\left(M^{z+}\right)$ at a carboxyl binding site, as described by Ferris (1997), results in the release of a proton according to the reaction:

$$
\mathrm{B}-\mathrm{COOH}+M^{z+}=\mathrm{B}-\mathrm{COOM}^{z-1}+\mathrm{H}^{+}
$$

Thus, the sorption of metal ions depends not only on the number of reactive chemical groups on the bacterial surface, but also on the $\mathrm{pH}$ and on the concentration of dissolved metal ions. The sorption of cationic species is enhanced as the $\mathrm{pH}$ increases and as surface groups deprotonate. As a result, the metal binding capacity of natural biofilms is enhanced significantly under circumneutral $\mathrm{pH}$ conditions, with respect to that in acidic metal-contaminated waters (Ferris 1997).

\section{Iron sulfides in marine sediments}

Iron sulfide minerals are ubiquitous both in modern anoxic sediments and in sedimentary rocks. The primary stages of sedimentary iron sulfide formation were identified by Berner (1970; 1984), and the topic has since been reviewed several times (Morse et al. 1987; Rickard et al. 1995; Schoonen 2004; Rickard and Morse 2005). For the past four decades, the key processes appeared to be well understood. The remaining uncertainties were related to the 
importance of specific reactions, the physical and chemical properties of transient phases, and the roles of microbes. However, the most recent review by Rickard and Morse (2005) challenged many long-standing views, and identified several areas where more research is necessary. Here, primary attention is paid to the aspects of sedimentary iron sulfide formation that are related to the activities of micro-organisms.

The formation of iron sulfides in sediments is a typical example of BIM. The rate of iron sulfide formation depends primarily on the rate of microbial sulfate reduction (which also depends on the availability of organic carbon), and on the amount of competing electron acceptors including reactive Fe(III)-bearing minerals (Berner 1970) (Fig. 11). When dissolved sulfide produced by SRP reacts with $\mathrm{Fe}^{2+}$, the precipitate that forms is generally termed "amorphous FeS," and appears to correspond to poorly-ordered or nanocrystalline mackinawite (Lennie and Vaughan 1996), or mixtures of mackinawite and greigite. Most earlier literature on sedimentary pyrite formation assumes that pyrite forms by the conversion of mackinawite or greigite (Schoonen 2004). However, according to Rickard and Morse (2005), these precursors are not required for pyrite formation.

Our understanding of the roles of bacteria in each pyrite-forming stage has changed considerably over the past ten years (Donald and Southam 1999; Schoonen 2004; Rickard and Morse 2005). Whereas the role of bacteria had been thought to be restricted to providing sulfide ions, it now appears that micro-organisms affect in many ways the processes that lead to the formation of iron sulfides (Fig. 11).

The mineral species. In addition to pyrite, which is the most abundant species, other iron sulfides that occur in sediments include mackinawite and greigite. The latter minerals (and pyrrhotite $\left(\mathrm{Fe}_{1-x} \mathrm{~S}\right)$ ) are also termed "iron monosulfides." Significantly, mackinawite and greigite have rarely been identified in the field. In most studies, the operationally-defined category of acid volatile sulfides (AVS) is used, and is assumed to include amorphous FeS, mackinawite, and greigite. However, as pointed out by Rickard and Morse (2005), AVS is not

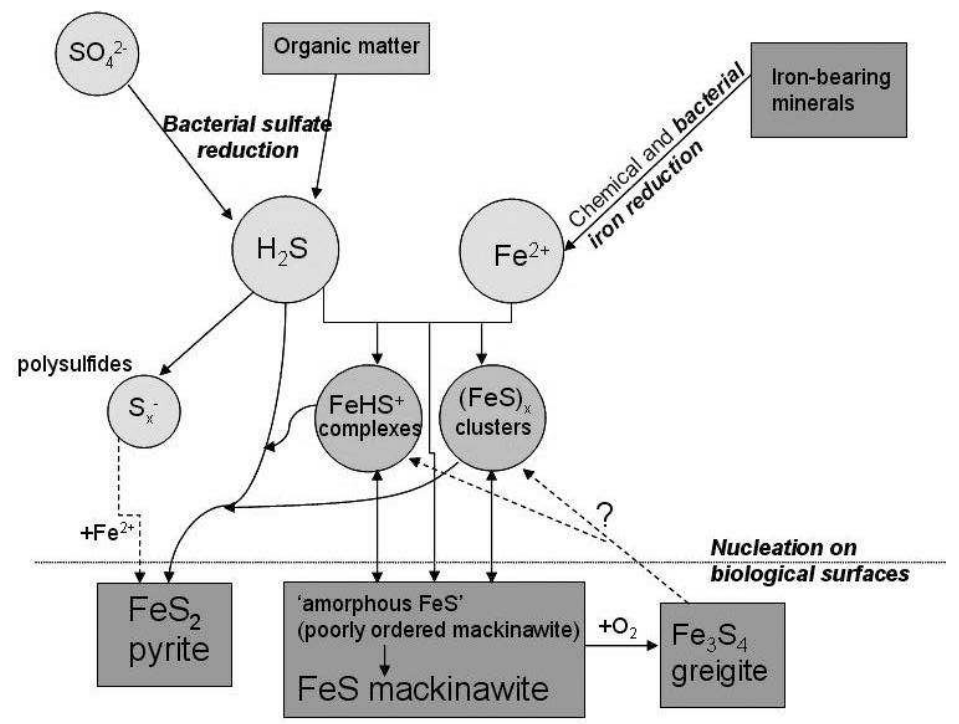

Figure 11. The primary pathways of sedimentary iron sulfide formation, based on Berner (1984) and Rickard and Morse (2005). Circles and rectangles denote dissolved and solid species, respectively. Text in italics refers to processes that involve the activity of bacteria. 
equivalent to the sum of solid iron monosulfides but is a complex and variable component of the sediment. AVS likely includes dissolved iron and sulfur species and their complexes, aqueous iron sulfide clusters $\left(\mathrm{FeS}_{\mathrm{aq}}\right.$ ) (see Rickard and Luther, 2006, in this volume), and an unidentified fraction of mackinawite and greigite. In addition, even though pyrite is insoluble in weak acids, commonly used extraction methods may partially dissolve fine-grained pyrite, which may then also contribute to AVS (Rickard and Morse 2005).

The thermodynamic constraints that determine which iron sulfide is stable in an anoxic sediment were discussed by Schoonen (2004). Iron monosulfides are predicted, by equilibrium thermodynamic calculations, to be stable over a very narrow range of $\mathrm{p} e-\mathrm{pH}$ conditions. Marcasite is metastable with respect to pyrite and forms under acidic conditions $(\mathrm{pH}<5)$ (Murowchick and Barnes 1986). Therefore, in equilibrium, only pyrite would be expected to occur in a low-temperature sedimentary environment. However, many field studies attest to the prevalence of iron monosulfides in modern marine sediments. In euxinic basins, the amount of iron monosulfides exceeds that of pyrite (Hurtgen et al. 1999). In addition, evidence has accumulated over the past 15 years that greigite is the primary carrier of magnetization in many types of sedimentary rock, some of which are as old as Cretaceous (Reynolds et al. 1994; Roberts 1995; Dekkers et al. 2000; Rowan and Roberts 2006; Pearce et al. 2006, in this volume). The presence of metastable iron monosulfides has generally been attributed to the presence of a high nucleation barrier for the formation of pyrite (Schoonen and Barnes 1991; Benning et al. 2000). If pyrite seed crystals are present, then this nucleation barrier can be overcome (Benning et al. 2000).

Availability of iron. The balance between the rate of $\mathrm{H}_{2} \mathrm{~S}$ formation and the availability of reactive iron exerts a controlling factor over FeS formation (Schoonen 2004). Raiswell and Canfield (1998) documented the importance of the mineral phase of iron oxide present in the sediment on the rate of its sulfidation. Highly reactive minerals include ferrihydrite, lepidocrocite, goethite, and hematite, with half-lives of less than a year. Magnetite and "reactive" iron silicates have half-lives on the order of $\sim 10^{2}$ years, whereas the half-lives of poorly reactive minerals (such as ilmenite and some silicates) are in the $10^{6}$-year range. As discussed above, dissimilatory metal-reducing bacteria use oxidized forms of iron as terminal electron acceptors, thereby causing the dissolution of oxide minerals under anaerobic conditions (Frankel and Bazylinski 2003; Kappler and Straub 2005). The released metal ions can participate in various mineral-forming reactions, including those that produce sulfides. Although inorganic and biogenic pathways for metal reduction are not easy to distinguish in most natural systems, bacterial processes are likely to be important for supplying iron for sedimentary iron sulfide formation (Rickard and Morse 2005).

Nucleation and the physical properties of mackinawite and greigite. The role of bacteria in the nucleation of iron monosulfides is uncertain, although there is evidence that FeS nucleates preferentially on the cell envelopes of SRP. Bacterial cells and their remains were found to be prominent nucleation sites for amorphous FeS (and nanocrystalline millerite, NiS) in a contaminated lake sediment (Ferris et al. 1987). Donald and Southam (1999) found that thin layers of FeS coated both the inner and the outer surfaces of cells. Anionic cell surface polymers likely interacted with $\mathrm{Fe}^{2+}$, and the immobilized cations could then react with $\mathrm{H}_{2} \mathrm{~S}$, forming the films of FeS. Similarly, iron sulfides encrusted the surfaces of SRP in experiments by Watson et al. (2000) (Fig. 12). They formed on the surface of hematite to which SRP were attached, and initiated the precipitation of FeS (Neal et al. 2001). Thus, micro-organisms are important nucleation sites for the formation of iron sulfides.

The initial FeS precipitate is difficult to characterize because of its small grain size and poorly ordered structure. The morphologies and sizes of nanocrystals appear to be strongly affected by experimental conditions. Whereas Wolthers et al. (2003) described FeS precipitates as nanocrystals with an average size of $\sim 4 \mathrm{~nm}$, Herbert et al. (1998) found that platy macki- 
nawite crystals with diameters of 100 to 300 $\mathrm{nm}$ precipitated in growth media of SRP, and formed 1 to $2 \mu \mathrm{m}$ spherical aggregates. Ohfuji and Rickard (2006) showed that mackinawite precipitated as nanocrystalline particles, and presented a list of particle sizes and specific surface areas observed in various studies. Structurally, all of these studies identified the primary phase of the precipitate as "poorly ordered" or nanocrystalline mackinawite, although Wolthers et al. (2003) described two types of crystalline domains ("MkA" and "MkB"), with different $d$-values that bore little resemblance to those of mackinawite. High-resolution TEM images and electron diffraction patterns were obtained from an FeS precipitate by Ohfuji and Rickard (2006). The diffraction patters contained diffuse rings, indicating that the particles were poorly ordered (Fig. 13). The observed $d$-spacings suggested that a mackinawite-like short-range order is present, consistent with the high-resolution images.

In addition to mackinawite, greigite was also identified in several studies in the initial FeS precipitate. Herbert et al. (1998) inferred that the surfaces of the aggregated nanocrystals had a greigite composition, whereas the remaining bulk material consisted of disordered mackinawite. On the basis of magnetic measurements, Watson et al. (2000) found that greigite formed a significant fraction of SRP-precipitated iron sulfide.

Greigite also forms from mackinawite by solid-state transformation. Two basic routes have been suggested, either through iron loss (Lennie et al. 1997) or through sulfur addition
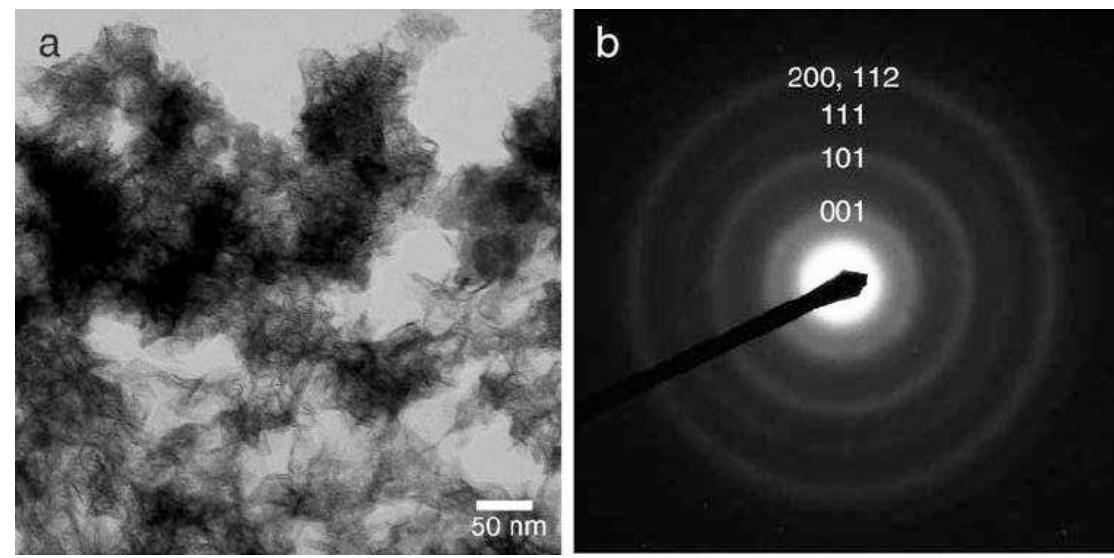

Figure 13. (a) TEM image and (b) electron diffraction pattern of precipitated mackinawite. [Used with permission of Elsevier, from Ohfuji and Rickard (2006), Earth and Planetary Science Letters, Vol. 241, Fig. 2a,b, p. 227-233.] 
(Horiuchi 1971). It appears that the conversion of mackinawite into either greigite or pyrite can be controlled by the presence of catalytic quantities of organic compounds (Rickard et al. 2001). In the presence of aldehydic carbonyls in the solution, $\mathrm{Fe}^{2+}$ in the iron monosulfide is partially oxidized, whereas $\mathrm{S}^{2-}$ remains unchanged, forming greigite. In the absence of aldehydic carbonyls, $\mathrm{S}^{2-}$ is oxidized and pyrite forms (Rickard et al. 2001). It is not yet known whether similar organic switches operate in natural systems as in the laboratory experiments.

The greigite that forms from mackinawite is also nanocrystalline. This observation has important implications for the magnetic properties of sediments. The magnetic single domain range for greigite is particle-shape-dependent and extends from $\sim 50 \mathrm{~nm}$ (Diaz-Ricci and Kirschvink 1992) to a poorly-constrained upper limit of 200-1000 nm (Hoffmann 1992; DiazRicci and Kirschvink 1992). Crystals within this range have a high coercivity and therefore contribute significantly to the remanent magnetism of sediments. Rowan and Roberts (2006) found that single-domain and superparamagnetic greigite populations coexisted in Neogene marine sediments, providing for a complex magnetic behavior. Greigite formed with pyrite in framboids, but a later generation of very fine-grained superparamagnetic greigite appeared to grow on the pyrite crystals. Such late diagenetic changes can complicate paleomagnetic interpretations, since such crystals aquired their remanence $>1$ Myr after deposition.

The formation of pyrite. Three primary pathways for pyrite formation are usually considered (Schoonen 2004), including (1) FeS oxidation by a polysulfide species (Luther 1991; Schoonen and Barnes 1991); (2) FeS oxidation by $\mathrm{H}_{2} \mathrm{~S}$ (Rickard 1997); and (3) conversion of $\mathrm{FeS}$ by iron loss through an intermediate greigite phase (Wilkin and Barnes 1996). The reactions are:

$$
\begin{aligned}
& \text { (1) } \mathrm{FeS}+\mathrm{S}_{n}{ }^{2-} \rightarrow \mathrm{FeS}_{2}+\mathrm{S}_{n-1}{ }^{2-} \\
& \text { (2) } \mathrm{FeS}+\mathrm{H}_{2} \mathrm{~S} \rightarrow \mathrm{FeS}_{2}+\mathrm{H}_{2} \\
& \text { (3) } 4 \mathrm{FeS}+1 / 2 \mathrm{O}_{2}+2 \mathrm{H}^{+} \rightarrow \mathrm{Fe}_{3} \mathrm{~S}_{4}+\mathrm{Fe}^{2+}+\mathrm{H}_{2} \mathrm{O} \\
& \mathrm{Fe}_{3} \mathrm{~S}_{4}+2 \mathrm{H}^{+} \rightarrow \mathrm{FeS}_{2}+\mathrm{Fe}^{2+}+\mathrm{H}_{2}
\end{aligned}
$$

Experimental tests by Benning et al. (2000) showed that Reaction (2) does not produce appreciable amounts of pyrite if $\mathrm{H}_{2} \mathrm{~S}$ is the only reactant in the system with mackinawite. Pyrite formation is induced only if the aqueous sulfur species or the mackinawite is oxidized. However, the importance of Reaction (2) is supported indirectly by the persistence and large proportion of iron monosulfide in euxinic sediments. In such an environment, reactive iron is available in abundance. Consequently, dissolved sulfide is depleted by iron sulfide formation, and the lack of dissolved sulfide prevents it from reacting with $\mathrm{FeS}$ and converting it into pyrite (Hurtgen et al. 1999). The conversion of mackinawite into greigite via iron loss (3) was observed by Lennie et al. (1997). On the basis of an analysis of molar volume changes, Furukawa and Barnes (1995) argued that the precursor phase converts to pyrite via the iron loss pathway (Reaction 3 above).

Studies by Luther and coworkers (Theberge et al. 1997; Luther et al. 2001; Luther and Rickard 2005) demonstrated the biogeochemical importance of aqueous metal sulfide complexes (see Rickard and Luther 2006, in this volume). Highly reactive $\mathrm{FeS}_{\mathrm{aq}}$ clusters appear to be key intermediaries in pyrite formation, as they react with either $\mathrm{H}_{2} \mathrm{~S}$ or polysulfide species to nucleate pyrite (Rickard and Morse 2005). In light of these results, the conversion of mackinawite or greigite into pyrite cannot be regarded as a solid-state transformation. Instead, these minerals may be partially dissolved, forming aqueous FeS clusters that react to form pyrite (Fig. 11). Since FeS clusters can form by other routes, the presence of mackinawite and greigite is not a necessary condition for pyrite formation (Rickard and Morse 2005).

Experiments by Donald and Southam (1999) indicated that the conversion of FeS to $\mathrm{FeS}_{2}$ is promoted by the formation of a thin FeS film on the surfaces of bacterial cells. Sulfur- 
disproportionating bacteria also appeared to play a role in converting organic sulfur into $\mathrm{H}_{2} \mathrm{~S}$ in experiments by Canfield et al. (1998). Since radiolabeled organic sulfur was incorporated into the final pyrite product in this study, the FeS to pyrite transformation took place via the sulfur addition pathway (reaction (1) above). Fortin and Beveridge (1997) observed the intact remains of SRP encrusted by iron sulfides, while Grimes et al. (2001) found that organic matter provided nucleation sites for the reaction of $\mathrm{FeS}$ to $\mathrm{FeS}_{2}$. It appears that bacterial activity mediates both the initial precipitation of $\mathrm{FeS}$ and its conversion to pyrite.

Framboidal pyrite. The interesting morphologies of sedimentary pyrite have long captivated the attention of researchers. A variety of morphological types occurs, including euhedral, irregular, and ooidic pyrite (Hámor 1994). However, the most widespread and characteristic appearance of pyrite is framboidal (Schoonen 2004; Ohfuji and Rickard 2005). The term framboid refers to a spherical structure, which consists of densely-packed pyrite crystals that have similar sizes and morphologies (Fig. 14). In addition to pyrite, greigite has also frequently been found as a component of framboids (Bonev et al. 1989; Wilkin and Barnes 1997; Rowan and Roberts 2006). The diameters of framboids are in the 1-30 $\mu \mathrm{m}$ range (but most are smaller than $10 \mu \mathrm{m}$ ), while the individual constituent crystals range from $\sim 0.1$ to $2 \mu \mathrm{m}$ (Wilkin et al. 1996). Framboids were once thought to be fossilized bacteria. They were then considered to be pyritized organic particles or colloids (Raiswell et al. 1993) or abiotic products of the conversions of magnetic precursor iron sulfides, i.e., greigite (Sweeney and Kaplan 1973; Wilkin and Barnes 1997). However, Butler and Rickard (2000) synthesized pyrite framboids in the absence of magnetic intermediates and biological intervention. They found that the framboidal texture results from rapid nucleation from a strongly supersaturated solution, through the reaction of aqueous FeS cluster complexes with $\mathrm{H}_{2} \mathrm{~S}$ (see Rickard and Luther 2006, in this volume). Thus, even though the peculiar morphologies of framboids are suggestive of biological processes, the development of framboids may be the least likely of the various stages of sedimentary pyrite formation to be affected by biogenic activity.

Since framboids form either in the water column (in euxinic environments) or during early diagenesis within the top few centimeters of the sediment, their sizes reflect the conditions of the environment of deposition. In a very thorough study of framboid size distributions, Wilkin et al. (1996) established relationships between the size distributions of pyrite framboids and the redox conditions of the depositional environment.

Framboids can have remarkably ordered architectures, forming either cubic or icosahedral close-packed structures (Ohfuji and Akai 2002). In an electron backscatter
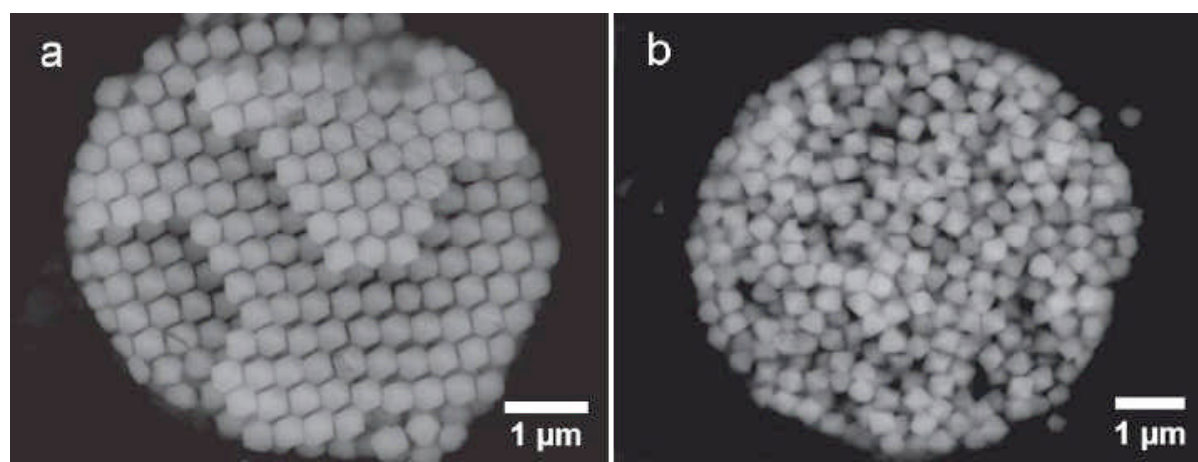

Figure 14. SEM images of synthetic pyrite framboids. (a) Morphologically ordered and (b) disordered framboid. [Used with permission of Elsevier, from Ohfuji and Rickard (2006), Earth Science Reviews, Vol. 71, Fig. 1a,c, p. 147-170.] 
diffraction study, Ohfuji et al. (2005) distinguished morphologically ordered and disordered framboids (Fig. 14), and determined the morphological and crystallographic orientations of individual nanocrystals. Even in morphologically ordered framboids, low- and high-angle crystallographic misorientations were observed, the latter resulting from the fact that pyrite has only a two-fold axis along $<100>$. The results suggested that the self-organized structure results from the aggregation and subsequent reorientation of equimorphic nanocrystals.

\section{Biogenic zinc sulfides: from mine-water to deep-sea vents}

The biologically mediated precipitation of zinc sulfide has been studied recently in two widely different natural systems, in a flooded lead-zinc mine (Labrenz et al. 2000; Moreau et al. 2004) and in the tubes of a deep-sea vent worm (Zbinden et al. 2001, 2003; Maginn et al. 2002). Remarkably, the $\mathrm{ZnS}$ minerals that formed in these distinct environments showed similar morphological and chemical features.

Spherical aggregates of $\mathrm{ZnS}$ formed in a biofilm of sulfate-reducing bacteria in the flooded tunnel of a carbonate-hosted Pb-Zn deposit (Labrenz et al. 2000). The spherules were 1 to $5 \mu \mathrm{m}$ in diameter and consisted of 1 to $5 \mathrm{~nm}$, semi-randomly oriented, crystalline $\mathrm{ZnS}$ nanoparticles (Fig. 15). Both sphalerite and wurtzite structures occured within the nanoparticles, and stacking faults, twins, and disordered sequences of close-packed layers were observed to be present in many nanocrystals (Moreau et al. 2004). The $\mathrm{ZnS}$ particles were chemically pure, with no measurable iron content, and occured in layers within the biofilm, in close association with bacterial cells or extracellular polymeric material. The bacteria were shown by small-subunit ribosomal RNA gene analyses to belong to the sulfate-reducing family Desulfobacteriaceae, and verified to be metabolically active by fluorescence in situ hybridization (Labrenz et al. 2000). Some cells were encrusted and fossilized by $\mathrm{ZnS}$ spheroids, indicating the intimate association of bacteria and $\mathrm{ZnS}$ mineralization. Thus, the $\mathrm{ZnS}$ precipitation at this site was wholly attributable to the activity of SRP (Moreau et al. 2004).

The precipitation of pure $\mathrm{ZnS}$ consisting of both sphalerite and wurtzite structural elements is an interesting feature of this biomineralization. According to experimentally determined stability fields (Scott and Barnes 1972), sphalerite should form from cold $\left(8-10^{\circ} \mathrm{C}\right)$ groundwater. However, the presence of wurtzite is consistent with a size-dependence of $\mathrm{ZnS}$ phase stability, which has been predicted by molecular dynamics simulations (Zhang et al. 2003).

The extreme environment of deep-sea hydrothermal vents of the East Pacific Rise hosts the alvinellid or so-called Pompeii worms (Alvinella

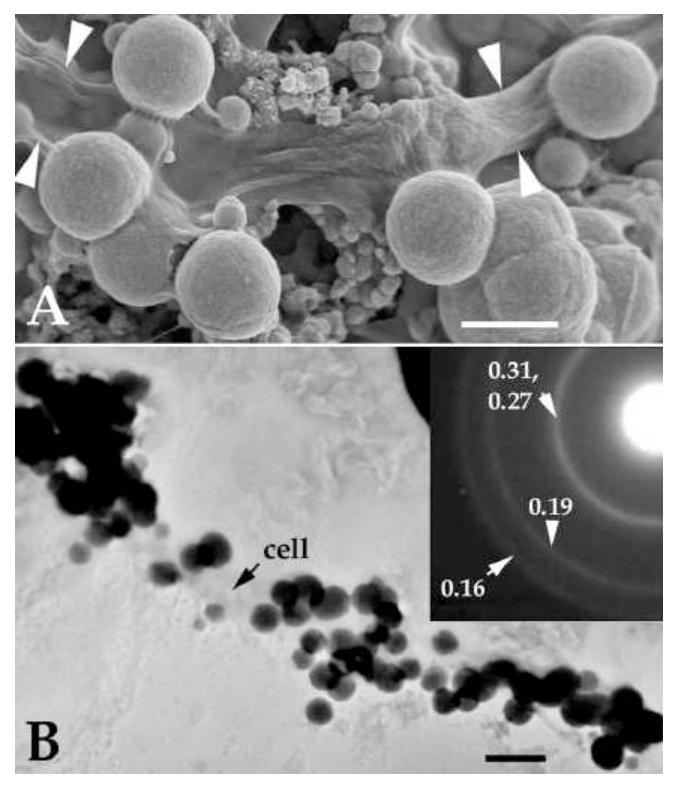

Figure 15. (a) SEM image of spherical $\mathrm{ZnS}$ aggregates that are associated with a biofilm (marked by arrowheads) from a flooded lead-zinc mine. (b) TEM image and selected-area electron diffraction pattern, showing that the $\mathrm{ZnS}$ spherules are associated with bacterial cells, and that both sphalerite and wurtzite structural elements occur in the spherules. [Reprinted with permission from Labrenz et al., Science, Vol. 290, Fig. 2a,b, p. 1744-1747. Copyright (2000) AAAS.] 
pompejana and Alvinella caudata) (Zbinden et al. 2003). These animals dwell in organic tubes that contain zinc and iron sulfide minerals. The worms live on active sulfide chimney walls, where they are exposed to steep thermal and chemical gradients and intense mineral precipitation (Desbruyeres et al. 1998). Since sulfide-rich hydrothermal fluids and seawater mix within the worm tubes, the inorganic chemical deposition of sulfide minerals is possible. However, whereas hydrothermally-precipitated $\mathrm{ZnS}$ grains outside the worm tubes have variable iron contents and crystal sizes, the mineral grains in the tube wall have specific compositions, grain sizes, and positions within the wall structure (Zbinden et al. 2001, 2003). The specific properties of the minerals reflect the direct effects of the biological environment.

The worm tubes consist of concentric layers of fibrous organic material. The inner surface of the tube is covered by filamentous bacteria and $\mathrm{ZnS}$ grains. Each time the worm secretes a new layer, the bacteria and the minerals become entombed in the organic matrix of the tube (Zbinden et al. 2001, 2003) (Fig. 16). The spherical ZnS grains are aggregates of 1-5 nm crystals, and have a remarkably uniform composition of $\mathrm{Zn}_{0.88} \mathrm{Fe}_{0.12} \mathrm{~S}$. Powder electron diffraction patterns obtained from the round $\mathrm{ZnS}$ grains are consistent with the structures of both sphalerite and wurtzite (Zbinden et al. 2001). The sulfide mineral aggregates are attached to sheathed and branching bacterial filaments that occur on the inner tube surfaces (Maginn et al. 2002).

A specific feature of the mineralization associated with the Pompeii worms is that mineralogical gradients are present both from the outside to the inside and from the bottom to the top of the tubes (Zbinden et al. 2003). $\mathrm{FeS}_{2}$ minerals predominate on the bottom outer surfaces of the tubes, with a marcasite to pyrite ratio of approximately $3: 1$. The relative proportion of $\mathrm{FeS}_{2}$ minerals decreases from the bottom to the top of the tubes. Whereas Zbinden et al. (2003) found no iron sulfide in the mineralized layers within the tube wall and on the inner surfaces of the tubes, Maginn et al. (2002) observed pyrite, marcasite and other iron sulfides (presumably mackinawite and greigite) associated with $\mathrm{ZnS}$ inside the tubes. Although the particular features of the zinc and iron sulfide distributions may change between worm tubes observed in various sites, the mineralogical gradients indicate that the fluid compositions inside
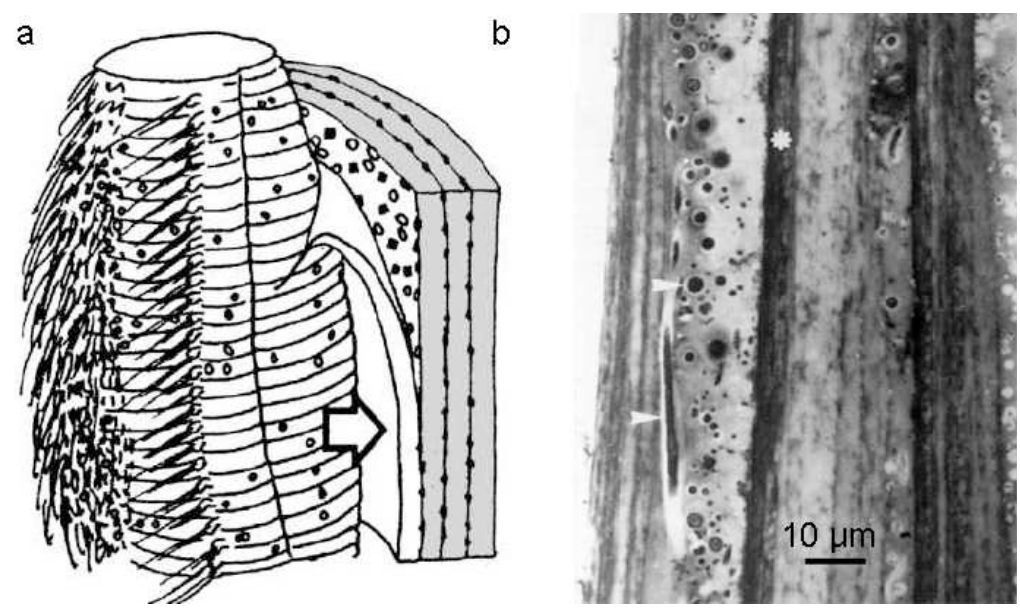

Figure 16. (a) A sketch of an Alvinellid worm and its tube. The worm secretes a new layer on the inside of the tube. The black dots represent $\mathrm{ZnS}$ grains and bacteria that are present on the surfaces of the tube layers. (b) Optical micrograph of a cross-section of several layers of an Alvinellid tube. The arrowheads indicate entrapped bacteria. The left side of the figure corresponds to the inside of the tube. [Used with permission of Schweizerbart (http://www.schweizerbart.de), from Zbinden et al. (2001), European Journal of Mineralogy, Vol. 13, Figs. 1, 5, p. 653-658.] 
and outside the tube differ. Either the worm creates special hydrodynamic conditions within the tube, and thereby changes the ratio of vent fluid and seawater with respect to the conditions outside the tube (Desbruyeres et al. 1998), or the metabolic activity of the worm or its epibiotic bacteria causes the exclusive formation of $\mathrm{ZnS}$ minerals inside the tube (Zbinden et al. 2003).

There are some remarkable similarities between the $\mathrm{ZnS}$ minerals in the worm tubes and in the biofilm that was recovered from the groundwater in the lead-zinc mine. The sizes of the $\mathrm{ZnS}$ nanocrystals, and even those of the aggregate spherules, are similar in both cases. It is likely that the nanocrystals in the worm tubes have disordered layer sequences, similar to those in the sphalerite/wurtzite grains from the mine-water. Although the mineral grains from the mine are pure $\mathrm{ZnS}$, while the crystals in the worm tubes contain iron, both types of biogenic $\mathrm{ZnS}$ are characterized by constant compositions. All of these features indicate that even minerals that are formed by BIM can have characteristics that distinguish them from inorganically-formed crystals. Although the bacteria that were found on the inner surface of the worm tube were not isolated and cultured, their close association with the $\mathrm{ZnS}$ grains suggests that they may be sulfate reducers, and that they could play a role in the detoxification of the fluid surrounding the worm (Zbinden et al. 2001).

\section{BIOLOGICALLY MEDIATED DISSOLUTION OF SULFIDE MINERALS}

The dissolution of sulfide minerals has important ramifications, both globally and locally, since it affects global geochemical cycles, generates acid mine drainage (AMD), and is used in industrial metal extraction. There is a long history of research on micro-organisms that oxidize sulfur or iron or both, and thereby enhance the rates of sulfide mineral weathering. Here, a few aspects of sulfide bioweathering are discussed. For comprehensive reviews on the geomicrobiology of sulfide mineral oxidation, the reader is referred to Nordstrom and Southam (1997) and McIntosh et al. (1997). The microbiological cycling of iron was recently reviewed by Kappler and Straub (2005).

\section{Acid mine drainage}

Wherever sulfide-bearing rocks or mine tailings are exposed to oxidative conditions, the sulfide minerals dissolve and produce acidic waters (Jambor et al. 2000). AMD is a major environmental concern, since the acidity of the water (generally between $\mathrm{pH} 2$ and 4), as well as the presence of toxic concentrations of metals, are detrimental for many aquatic organisms. Although the oxidation of many sulfide mineral species contributes to AMD, pyrite is usually considered to be the most abundant and important mineral involved in the production of acidic waters (for a review of studies of the oxidation of various sulfides see Nordstrom and Southam 1997, and for the reaction products see Jambor et al. 2000).

Chemical and microbial processes are coupled in the generation of AMD. Under oxidative conditions, sulfide minerals react with oxygen, and the reaction is catalyzed by iron and sulfur-oxidizing bacteria. Members of the bacterial genus Thiobacillus are the most widely studied micro-organisms that break down sulfide minerals. Other important genera include Leptospirillum, Sulfobacillus, and some species of Archaea (Davis 1997; Nordstrom and Southam 1997; Baker and Banfield 2003). Most of these bacteria are acidophilic lithoautotrophs, i.e., they require an environment with a $\mathrm{pH}<3$ for optimal growth, and they use inorganic compounds as their source of metabolic energy (McIntosh et al. 1997). Microbial processes in the anoxic sections of mine tailings also contribute to the cycling of metals and sulfur, but these processes are still poorly understood (Fortin et al. 2002). Research into microbial communities involved in the production of AMD was recently reviewed by Baker and Banfield (2003).

The mechanism of bacterial catalysis of sulfide mineral oxidation was discussed by Nordstrom and Southam (1997). There has been some controversy over the role of a hypothesized, 
direct enzymatic reaction induced by bacterial cells that attach to the mineral surface. The existence of such a reaction mechanism was supported by observations of etch pits that reflected the effects of attached cells (Bennett and Tributsch 1978). However, Nordstrom and Southam (1997) provided a comprehensive analysis of the observed rates of specific abiotic and biotic reactions that are involved in pyrite oxidation, and concluded that these data are consistent with the indirect microbial catalysis of sulfide mineral dissolution. The primary role of the bacteria is the oxidation of aqueous $\mathrm{Fe}^{2+}$ into $\mathrm{Fe}^{3+}$ under acidic conditions, according to the reaction:

$$
\mathrm{Fe}^{2+}+1 / 4 \mathrm{O}_{2}+\mathrm{H}^{+}=\mathrm{Fe}^{3+}+1 / 2 \mathrm{H}_{2} \mathrm{O}
$$

The ferric iron then attacks the mineral surface, and pyrite is oxidized at a rate that is determined by the bacterial oxidation step:

$$
\mathrm{FeS}_{2}+14 \mathrm{Fe}^{3+}+8 \mathrm{H}_{2} \mathrm{O}=15 \mathrm{Fe}^{2+}+\mathrm{SO}_{4}{ }^{2-}+16 \mathrm{H}^{+}
$$

Thus, although bacteria preferentially adhere to mineral surfaces in order to reduce the distance for the diffusion of iron between the mineral and the bacterium, there is no need to invoke an enzymatic reaction for sulfide mineral degradation (Nordstrom and Southam 1997).

The effects of cell attachment on mineral dissolution are the subject of continued interest. Edwards et al. (2001) experimented with reacting pyrite, marcasite, and arsenopyrite with the iron-oxidizing bacterium Acidithiobacillus ferrooxidans, the archaeon Ferroplasma acidarmanus, and abiotically with $\mathrm{Fe}^{3+}$. Interestingly, in both the biotic and the abiotic experiments, bacillus-sized etch pits developed on pyrite, indicating that the attachment of cells is not necessary for the development of etch pits with characteristic shapes and sizes. However, attached cells of $F$. acidarmanus induced pitting on the more reactive surface of arsenopyrite (Fig. 17). Thus, the reactivity of the mineral may determine whether the surface features that develop during oxidative dissolution are related directly or indirectly to the presence of micro-organisms (see also Rosso and Vaughan 2006, in this volume).

Despite a century of research, the rate of microbially-assisted oxidation of sulfide minerals under natural conditions is still uncertain (Edwards et al. 2000). Laboratory experiments that involved the use of the same strain of Thiobacillus ferrooxidans, the same pyrite source, and the same experimental procedures resulted in consistent and reproducible rates, with the rate of microbial iron release being 34 times larger than the abiotic rate (Olson 1991). In contrast, field studies showed a wide variety in the degree of microbial enhancement of chemical processes. For example, in the AMD at the ore body of Iron Mountain, California, microbial
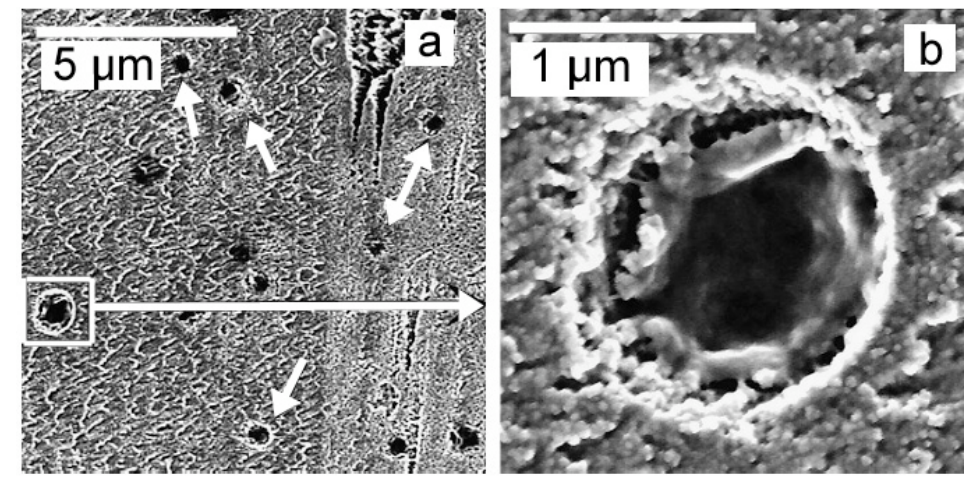

Figure 17. (a) Etch pits on the surface of arsenopyrite that was reacted with F. acidarmanus. (b) Magnified image of the area shown within the square in (a). The dehydrated cell in (b) is situated within a cellsized and -shaped dissolution pit. Other cells are indicated with arrows in (a). [Used with permission of Blackwell Publishing, from Edwards et al. (2001), FEMS Microbiology Ecology, Vol. 34, Fig. 10, p. 203.] 
enhancement of iron release was found to be much lower ( $\sim 3 \times$ the rate of the abiotic reaction) than in laboratory studies (Edwards et al. 2000). Several poorly-constrained factors, including the surface area that is available for reaction, and the properties of pore fluids (that determine microbial population densities) affect the rates of microbial and abiotic contributions to AMD (Edwards et al. 2000).

In addition to the well-known case of sulfide mineral dissolution under oxidative and acidic conditions, sulfides can be dissolved at higher $\mathrm{pH}$ and anoxic conditions. Significant bacterially-assisted dissolution of copper from its sulfide minerals was observed in the slightly alkaline water of a tropical river, downstream of a large copper mine (Simpson et al. 2005b). Although the bacteria that were responsible for the copper release could not be isolated, indirect evidence suggested that they were lithoautotrophs. The fate of sulfide minerals and the cycling of metals in AMD are complicated further by the presence of SRP and iron-reducing bacteria in the anoxic portions of mine tailings (Fortin et al. 2002). The activity of these organisms results in the re-precipitation of sulfide minerals and a reduction in metal concentration in the solution (as discussed below in the section on bioremediation).

\section{Microbial degradation of sulfides in marine environments}

Vast quantities of sulfide minerals are present on and beneath the seafloor, in widely varying environments, including marine sediments, hydrothermal systems associated with mid-ocean ridges, and in the bare basaltic rocks on the flanks of mid-ocean ridges (Edwards et al. 2005). Wherever sulfides are in contact with the oxic seawater, the possibility of their dissolution arises. As for AMD generation, both chemical and biogenic processes are involved in the breakdown of sulfides in marine environments. However, there appear to be significant differences between the roles of bacteria in geologically distinct regions of the seafloor.

The pyrite and iron monosulfides that form by BIM within the anoxic sediments can be transported by bioturbation to the surface of the sediment, where they are oxidized chemically by $\mathrm{O}_{2}$ (Thamdrup et al. 1994; Schippers and Jørgensen 2002). In the process, bacterial involvement may be limited to the oxidation of aqueous sulfur-bearing compounds, intermediates that result from the oxidation of pyrite, into sulfate (Kuenen et al. 1992). The bacterially-assisted oxidation of sulfide minerals under anoxic conditions was also considered by Schippers and Jørgensen (2002), who found that iron monosulfides could be oxidized by $\mathrm{Fe}^{2+}$ - or $\mathrm{H}_{2} \mathrm{~S}$-oxidizing and $\mathrm{NO}_{3}{ }^{-}$-reducing bacteria, but pyrite was not attacked by the same processes. Since many metals can be incorporated into iron sulfides, it is of environmental importance to trace the fate of these metals during their oxidation (Bertolin et al. 1995). Since iron monosulfides oxidize more readily than pyrite, they are prone to release incorporated metals (Holmes 1999). In general, there is no uniform behavior of pollutant metals. Whereas some metals remain in the particulate phase, others dissolve, depending on the particular environmental conditions (for a review see Schoonen 2004).

The potentially significant role of micro-organisms in the alteration of seafloor sulfide minerals at hydrothermal vents and in exposed basalt is just beginning to be addressed (as reviewed by Edwards et al. 2005). Hydrothermal metal sulfide deposits support communities of lithoautotrophic bacteria, among which sulfide- and iron- or manganese-oxidizing microbes promote the oxidative surface reaction of sulfide minerals. Verati et al. (1999) observed an external layer on black smoker chimneys that consisted of the oxidation products of sulfides and contained the imprints of bacterial cells. They concluded that bacterial sulfur and iron oxidation are responsible for the weathering of the sulfides. Schrenk et al. (2003) found diverse communities within hot, active black smoker chimney structures. Primarily archaea were found inside the chimneys, whereas in the external, cooler portions of the chimney walls bacteria dominated. In contrast, cold, inactive black smoker chimneys harbored only bacterial communities (Suzuki et al. 2004). Both iron- and sulfur-oxidizing lithoautotrophic bacteria 
were cultured from extinct chimneys, indicating their likely role in the weathering of black smoker sulfides (Edwards et al. 2005).

In an in situ incubation study, several minerals (pyrite, marcasite, chalcopyrite, sphalerite, elemental sulfur) and a fragment of a natural black smoker chimney were left to react for two months in the vicinity of a seafloor hydrothermal system (Edwards et al. 2003). The surfaces of these minerals were colonized by bacteria, likely belonging to iron- and sulfur-oxidizing species. The colonization densities were found to correlate positively with the abiotic reactivity of the minerals, i.e., the more reactive was the mineral, the more cells colonized its surface. The only exception was elemental sulfur, which was both the most heavily colonized and the least reactive. The black smoker chimney fragment was even more heavily colonized and weathered than the individual minerals, suggesting that the weathering of natural, fine-grained sulfide structures is enhanced significantly by micro-organisms (Edwards et al. 2003).

Rock-hosted microbial communities on the seafloor are not restricted to hydrothermal chimney structures. Geographically vast regions exist on the flanks of mid-ocean ridges, which consist of unsedimented basalt and are potential targets for the colonization of lithoautotrophic micro-organisms. Iron-oxidizing bacteria were inferred to be present on the ocean basalt (Thorseth et al. 2001), and uncultured bacteria from deep-sea basalt were genetically similar to known sulfur- and iron-metabolizing bacteria (Lysnes et al. 2004).

Hydrothermal fluids mix with seawater in a shallow, sub-seafloor region, which is inferred to host a "deep biosphere" of endolithic microbial communities (Summit and Baross 2001). Such habitats are not yet accessible for direct sampling, but diffuse vents on ridge flanks are thought to offer a glimpse into the sub-seafloor biota (Edwards et al. 2005). Microbial populations in the diffuse vents were found to be distinct from those in the bottom seawater (Huber et al. 2003). The study of the interactions between microbes and minerals on and below the seafloor is a new field, which will likely bring interesting results concerning the bioassisted precipitation and alteration of sulfide minerals.

\section{PRACTICAL APPLICATIONS OF INTERACTIONS BETWEEN ORGANISMS AND SULFIDES}

\section{Biomimetic materials synthesis}

The processes that are involved in biologically controlled mineralization provide valuable insights for materials chemists. "Bio-inspired materials chemistry" makes use of strategies learned from studies on biominerals, and has developed into a large field (Mann 2001). Various types of nanocrystals are synthesized using biomimetic approaches, including several sulfides. Here we mention a few typical examples for the concepts and strategies that are applied-for further reading we recommend the books by Mann (1997, 2001).

In BCM, crystals often precipitate in confined spaces such as phospholipid vesicles or ferritins (Table 1). Similar artificial vesicles can be used to create nanoscale reaction droplets. For example, ferritin is a spherical protein cage with an internal space about $8 \mathrm{~nm}$ in diameter that normally contains ferrihydrite (Mann 2001). The supramolecular structure of ferritin is remarkably stable, and the iron oxide core can be removed chemically without affecting the protein shell. Either empty ferritin cages can be used as confined reaction spaces, or the iron oxide core can be transformed chemically. The latter approach was used to produce amorphous FeS particles with controlled sizes ranging from 2 to $7 \mathrm{~nm}$ (Meldrum et al. 1991). Semiconducting CdS nanocrystals were synthesized both in reverse micelles and as the cores of artificial ferritin (Wong and Mann 1996). By attaching antibodies and antigens to the proteins, the ferritin cages can be linked together in solution, and a network of preformed, protein-coated inorganic nanoparticles can be engineered. 
Functionalized organic structures can be used as epitaxial surfaces for templating the nucleation and growth of inorganic crystals. Oriented crystals of $\mathrm{PbS}$ were synthesized on selfassembled surfactant films (Langmuir monolayers) (Belman et al. 2004), while the ordered structures of bacterial S-layers proved to be an efficient template for the nucleation of ordered two-dimensional arrays of 5-nm CdS nanoparticles (Shenton et al. 1997).

\section{Bioremediation}

As iron sulfides precipitate in marine sediments, minor and trace amounts of various metals can be incorporated into the structures of iron monosulfides and pyrite. Schoonen's review (2004) contains an extensive compilation of observed metal concentrations in pyrite. Since many of the metal and metalloid impurities are toxic, it is of considerable interest to determine whether the host minerals are stable sinks for these metals. Iron sulfide formation under anoxic conditions in mine tailings and wetlands can be exploited for the immobilization of metal contaminants (Fortin and Beveridge 1997; Paktunc and Dave 2002). A wide range of metals has been co-precipitated with bacterially-produced iron sulfide (Watson and Ellwood 1994). Pesumably, greigite was one of the components of the precipitated sulfide, since the product could be divided into a weakly and a strongly magnetic fraction (Watson et al. 2000). The immobilization of heavy metals in magnetic iron sulfides offers the possibility of removing the contaminants by magnetic separation methods.

In the flooded $\mathrm{ZnS}$ mine that was described by Labrenz et al. (2000), coupled geochemical and microbial processes efficiently strip $\mathrm{Zn}$ from solutions containing $<1 \mathrm{ppm} \mathrm{Zn}$. The biofilm contains $\mathrm{Zn}$ in a concentration of about a million times that of the groundwater. As discussed by Moreau et al. (2004), some of the sedimentary sulfide deposits may have formed by similar $\mathrm{BIM}$ processes. Since metals such as $\mathrm{As}, \mathrm{Se}, \mathrm{Cd}$, and $\mathrm{Pb}$ can be incorporated into or adsorbed on $\mathrm{ZnS}$ minerals, biomineralization may provide a suitable means to control the concentration of toxic metals in groundwater or wetlands. Such bioremediation strategies require that the minerals are relatively stable against dissolution. The solubilities of both sphalerite and wurtzite decrease with coarsening, since the growth of particles reduces the surface-to-volume ratio, decreasing reactivity with respect to oxidative dissolution (Moreau et al. 2004).

There are many possibilities for environmental applications of sulfide mineral precipitation by the mediation of bacteria. As discussed by Lovley (2003), bioremediation has been an empirical practice, but it could transform into a science thanks to new environmental genomic techniques that have become available. Experimental genomic and modelling techniques can be used to understand the physiologies of uncultured micro-organisms, and the resulting biological information, when combined with geochemical models, will be an invaluable tool for designing bioremediation strategies.

\section{Bioleaching of metals}

Whereas acidophilic, iron- and sulfur-oxidizing bacteria may be a curse when acid mine drainage is concerned, they are a blessing when used for the leaching of metals from their sulfide ores. Bacterial leaching of metals from low-grade ores is a well-established industrial technology that has been used for centuries (Rawlings and Silver 1995). Primarily mesophilic micro-organisms, such as Thiobacillus ferrooxidans, Thiobacillus thiooxidans, and Leptospirillum ferrooxidans, are applied (Hackl 1997). Historically, the targets of bacterial leaching have been sulfidic copper and refractory gold ores, but bioleaching practices are now used for the solubilization of a wide range of metals from their sulfide minerals (Nemati et al. 1998; Pina et al. 2005).

The use of bacteria in mineral processing may have additional advantageous side-effects. When T. ferrooxidans was added to a mixture of sulfide minerals during flotation, the cells adhered preferentially to pyrite and thus suppressed its floatability (Nagaoka et al. 1999). By 
using the microbes, pyrite could be separated from chalcocite, molybdenite, millerite, and galena. A detailed discussion of bioleaching practices is beyond the scope of this chapter. The interested reader is referred to reviews by Brierley (1978) and Hackl (1997).

\section{IRON SULFIDES AND THE ORIGIN OF LIFE}

Any review of the role of sulfide minerals in biosystems would be incomplete without mentioning the hypotheses that implicate sulfides in the origins of life. However, this topic is much more complex than is possible to deal with within the scope of this chapter. Also, an entire issue of the magazine Elements (June 2005) was devoted to problems related to the geochemical origin of life. Therefore, here the results of research on the possible roles of sulfides in the emergence of life are discussed only in the most general terms. The reader is referred to reviews by Cody (2005) and Schoonen et al. (2004).

Several origin-of-life hypotheses assume that the first organisms were autotrophs rather than heterotrophs, i.e., that they used small inorganic molecules (such as $\mathrm{CO}_{2}, \mathrm{NH}_{3}, \mathrm{H}_{2} \mathrm{~S}$, $\mathrm{H}_{2} \mathrm{O}, \mathrm{PO}_{4}{ }^{3-}$ ) for building their biomolecules. Since the conversion of the inorganic forms of biogenic elements $(\mathrm{C}, \mathrm{N}, \mathrm{O}, \mathrm{S}, \mathrm{H}$, and $\mathrm{P})$ requires energy or the surpassing of an activation barrier (Schoonen et al. 2004), a catalyst is necessary. Modern biocatalysts that promote the formation of organic molecules from small components include protein enzymes that contain clusters of transition metals (Fe, Ni, Co) and sulfur at their active sites (Beinert et al. 1997). The important roles of metal sulfide clusters in microbial biosynthesis inspired two distinct hypotheses by Wächtershäuser (1988, 1990) and Russell and Hall (1997), in both of which it was proposed that sulfide minerals could catalyze the production of the first biomolecules.

According to Wächtershäuser's theory $(1988,1990)$, the formation of pyrite could have provided the energy source for the first organism, reducing $\mathrm{CO}_{2}$ in the process, resulting in organic molecules according to the reaction:

$$
\mathrm{CO}_{2}(\mathrm{aq})+\mathrm{FeS}+\mathrm{H}_{2} \mathrm{~S} \rightarrow \mathrm{HCOOH}+\mathrm{FeS}_{2}+\mathrm{H}_{2} \mathrm{O}
$$

The small organic molecules then presumably combined into the larger biomolecules that are necessary for life. Some of the critical points of this hypothesis have been tested both experimentally and theoretically. Iron sulfide minerals were found to promote organic reduction reactions (Blöchl et al. 1992; Kaschke et al. 1994), while Huber and Wächtershäuser (1997) reported that a $(\mathrm{Ni}, \mathrm{Fe}) \mathrm{S}$ compound enhanced reactions that were designed to emulate the carbonyl-inserting reaction in modern microbial enzymes that have key roles in inorganic carbon fixation. However, on the basis of thermodynamical considerations, Schoonen et al. (1999) showed convincingly that the $\mathrm{FeS}-\mathrm{H}_{2} \mathrm{~S} / \mathrm{FeS}_{2}$ redox couple is unlikely to initiate the proposed prebiotic carbon fixation cycle. The key point of their study is that the reducing power of the $\mathrm{FeS}-\mathrm{H}_{2} \mathrm{~S} / \mathrm{FeS}_{2}$ couple diminishes with increasing temperature, whereas the reduction of $\mathrm{CO}_{2}$ and the formation of carboxylic acids require increasingly higher reducing power with temperature. Nevertheless, transition metal sulfides do act as catalysts for reactions that can form important organic molecules. Cody et al. (2001, 2004) showed that NiS and common minerals (including chalcopyrite, bornite, and chalcocite) have the capacity to convert simple organic molecules into carboxylic acids. These reactions appeared to be surface-catalyzed, since they resulted in a high degree of isomeric selectivity and the reaction yield was correlated with mineral surface area. In another interesting experiment, Bebié and Schoonen (1999) demonstrated that anionic phosphate and phosphorylated organic molecules interacted with the surface of pyrite, and suggested that phosphate could have been concentrated on metal sulfide minerals on a prebiotic Earth, promoting the selective concentration of organic molecules from aqueous solutions.

The origin-of-life hypothesis developed by Russell and Hall (1997) is based on a geochemical consideration of the conditions that may have prevailed on the young Earth. 
Soon after the discovery of hot vents on the deep seafloor, it was suggested that they provided the only stable environment where life could have emerged (Corliss et al. 1981). Shock (1992) demonstrated the potential for the formation of various organic molecules when $\mathrm{CO}_{2}$ and carbonates in seawater mix with hydrothermal solutions. Russell and Hall (1997) and Russell et al. (1998) argued that life started at a redox and $\mathrm{pH}$ front where the acidic and warm $(\sim 90$ $\left.{ }^{\circ} \mathrm{C}\right)$ water of the Hadean ocean merged with reduced, alkaline, bisulfide-bearing, hot $\left(\sim 150{ }^{\circ} \mathrm{C}\right)$ water emitted at diffuse submarine vents. Under these conditions, colloidal FeS precipitated spontaneously in the form of thin films. According to Russell and Hall (1997), such FeS films could have formed bubbles, creating semipermeable membranes that separated the two fluids with different chemistries. The assimilation of $\mathrm{CO}_{2}$ was catalyzed by the nickeliferous mackinawite, and amino acids and organic sulfide polymers could be synthesized within the FeS compartments. As the concentrations of carboxylic acids and organic polymers inside the bubbles increased, these organic molecules organized themselves either as coatings on the interiors of the FeS membrane or as micelles, and gradually took over the role of separating the two contrasting fluids. Thus, the first cell-like structures emerged, in which the generation of RNA and DNA may have become possible. The hypotheses by both Wächtershäuser (1988) and Russell and Hall (1997) are great intellectual achievements, and will likely continue to motivate much interesting experimental research in the future.

\section{CONCLUDING THOUGHTS}

Sulfide minerals were likely present at the beginning of life, and may even have catalyzed the first metabolic reactions at deep-sea hydrothermal vents. Interactions between organisms and sulfide minerals were important throughout most of Earth's history. Many types of sulfur-metabolizing microbes are rooted deeply in the Tree of Life, including sulfate reducers (Canfield and Raiswell 1999). A large radiation of sulfate reducers accompanied the general radiation of bacterial life. The formation of sulfide minerals by BIM must be at least as old as the first geochemical evidence for sulfate reduction, which is found between 2.7 and $2.5 \mathrm{Ga}$. Based on the available phylogenies, sulfate reducers may have appeared even earlier, by 3.4 Ga (Canfield and Raiswell 1999). Studies of the isotopic compositions of sedimentary pyrite led to the conclusion that the bottom waters of the oceans became sulfidic around $\sim 1.8 \mathrm{Ga}$, when increased atmospheric oxygen levels enhanced terrestrial sulfide weathering, supplying sulfate to the oceans and increasing the rate of sulfate reduction (Poulton et al. 2004). Sulfidic conditions may have persisted until between 0.8 and $0.58 \mathrm{Ga}$ ago, when a second major rise in oxygen concentration took place. At this time, the widespread oxidation of marine surface sediments promoted an evolutionary radiation of sulfide oxidizing bacteria (Canfield and Raiswell 1999), setting the stage for interactions between microbes and sulfide minerals as we know them today.

The geological history of sulfide mineral production by BCM is not known with any certainty. Sulfide magnetofossils from magnetotactic bacteria were identified tentatively from Miocene rocks (Pósfai et al. 2001) and soil (Stanjek et al. 1994). Since magnetite magnetofossils were described from Archaean rocks, Kirschvink and Hagadorn (2000) hypothesized that all $\mathrm{BCM}$ processes originated from magnetite biomineralization by magnetotactic bacteria.

Since biologically controlled or mediated mineralization produces nanocrystalline sulfide particles, their physical, structural, and chemical characterization will likely remain an exciting and challenging field of mineralogical research. Concerning the iron sulfides that are produced by magnetotactic bacteria, the key problems to be addressed are related to biological control over crystal nucleation and growth. It has still not been established whether greigite crystals in mangnetotactic bacteria are surrounded by a magnetosome membrane, as are the crystals in magnetite-producers, or whether they are deposited in a less controlled manner, 
perhaps as a consequence of the sulfate-reducing metabolism of the host cell. The mineral phases of the initially formed precipitates, as well as their conversions, also deserve further study. In addition, the possibility exists that additional sulfides with biological functions will be discovered. Given the geological and environmental importance of the bacterially-assisted formation and dissolution of sulfide minerals, interactions between microbes and sulfides will continue to be the subject of intensive research.

\section{ACKNOWLEDGMENTS}

We thank Takeshi Kasama for contributing the results of his electron holography work on magnetotatic bacteria, and Ryan Chong for electron tomography of sulfide-bearing bacteria. Samples and discussions with Richard Frankel and discussions with Peter Buseck are gratefully acknowledged. WMP acknowledges support from the Hungarian Science Fund (OTKA-T030186). RDB acknowledges the Royal Society for support.

\section{REFERENCES}

Aplin AC (2000) Mineralogy of modern marine sediments: A geochemical framework. In: Environmental Mineralogy. EMU Notes in Mineralogy 2. Vaughan DJ, Wogelius RA (eds) Eötvös University Press, p $125-172$

Baeuerlein E (2000) Biomineralization: From biology to biotechnology and medical application. Wiley

Baeuerlein E (2003) Biomineralization of unicellular organisms: An unusual membrane biochemistry for the produdction of inorganic nano- and microstructures. Angew Chem Int Ed 42:614-641

Baeuerlein E (2004) Biomineralization: Progress in biology, molecular biology and application. Wiley

Baker BJ, Banfield JF (2003) Microbial communities in acid mine drainage. FEMS Microbiol Ecol 44:139152

Balkwill DL, Maratea D, Blakemore RP (1980) Ultrastructure of a magnetic spirillum. J Bacteriol 141:13991408

Banfield JF, Cervini-Silva J, Nealson KH (eds) (2005) Molecular Geomicrobiology. Rev Mineral Geochem 59. Mineralogical Society of America

Banfield JF, Nealson KH (eds) (1997) Geomicrobiology: Interactions between microbes and minerals. Rev Mineral 35. Mineralogical Society of America

Bazylinski DA, Frankel RB (2003) Biologically controlled mineralization in prokaryotes. Rev Mineral Geochem 54:217-247

Bazylinski DA, Frankel RB (2004) Magnetosome formation in prokaryotes. Nat Rev Microbiol 2:217-230

Bazylinski DA, Frankel RB, Garratt-Reed AJ, Mann S (1990) Biomineralization of iron sulfides in magnetotactic bacteria from sulfidic environments. In: Iron Biominerals. Frankel RB, Blakemore RP (eds) Plenum Press, p 239-255

Bazylinski DA, Frankel RB, Heywood BR, Mann S, King JW, Donaghay PL, Hanson AK (1995) Controlled biomineralization of magnetite $\left(\mathrm{Fe}_{3} \mathrm{O}_{4}\right)$ and greigite $\left(\mathrm{Fe}_{3} \mathrm{~S}_{4}\right)$ in a magnetotactic bacterium. Appl Environ Microbiol 61:3232-3239

Bazylinski DA, Garratt-Reed AJ, Abedi A, Frankel RB (1993a) Copper association with iron sulfide magnetosomes in a magnetotactic bacterium. Arch Microbiol 160:35-42

Bazylinski DA, Heywood BR, Mann S, Frankel RB (1993b) $\mathrm{Fe}_{3} \mathrm{O}_{4}$ and $\mathrm{Fe}_{3} \mathrm{~S}_{4}$ in a bacterium. Nature $366: 218$

Bazylinski DA, Moskowitz BM (1997) Microbial biomineralization of magnetic iron minerals. Rev Mineral 35:181-223

Bebié J, Schoonen MAA (1999) Pyrite and phosphate in anoxia and an origin-of-life hypothesis. Earth Planet Sci Lett 171:1-5

Beinert H, Holm RH, Munck E (1997) Iron-sulfur clusters: Nature's modular, multipurpose structures. Science 277:653-659

Belman N, Berman A, Ezersky V, Lifshitz Y, Golan Y (2004) Transmission electron microscopy of epitaxial PbS nanocrystals on polydiacetylene Langmuir films. Nanotechnol 15:S316-S321

Bennett JC, Tributsch H (1978) Bacterial leaching patterns on pyrite crystal-surfaces. J Bacteriol 134:310-317

Benning LG, Wilkin RT, Barnes HL (2000) Reaction pathways in the Fe-S system below 100 degrees C. Chem Geol 167:25-51

Berner RA (1970) Sedimentary pyrite formation. Am J Sci 270:1-23

Berner RA (1984) Sedimentary pyrite formation: An update. Geochim Cosmochim Acta 48:605-615 
Berner RA (2001) Modeling atmospheric $\mathrm{O}^{-2}$ over Phanerozoic time. Geochim Cosmochim Acta 65:685-694

Bertolin A, Frizzo P, Rampazzo G (1995) Sulfide speciation in surface sediments of the Lagoon of Venice - a geochemical and mineralogical study. Mar Geol 123:73-86

Beveridge TJ (1989) Role of cellular design in bacterial metal accumulation and mineralization. Ann Rev Microbiol 43:147-171

Blakemore RP (1975) Magnetotactic bacteria. Science 190:377-379

Blöchl E, Keller M, Wächtershäuser G, Stetter KO (1992) Reactions depending on iron sulfide and linking geochemistry with biochemistry. Proc Nat Acad Sci USA 89:8117-8120

Bonev IK, Khrischev KG, Neikov HN, Georgiev VM (1989) Mackinawite and greigite in iron sulphide concretions from Black Sea sediments. Compt Rend Acad Bulg Sci 42:97-100

Brierley CL (1978) Bacterial leaching. CRC Crit Rev Microbiol 6:207-262

Butler IB, Rickard D (2000) Framboidal pyrite formation via the oxidation of iron (II) monosulfide by hydrogen sulphide. Geochim Cosmochim Acta 64:2665-2672

Canfield DE, Habicht KS, Thamdrup B (2000) The Archean sulfur cycle and the early history of atmospheric oxygen. Science 288:658-661

Canfield DE, Raiswell R (1999) The evolution of the sulfur cycle. Am J Sci 299:697-723

Canfield DE, Thamdrup B, Fleischer S (1998) Isotope fractionation and sulfur metabolism by pure and enrichment cultures of elemental sulfur-disproportionating bacteria. Limnol Oceanogr 43:253-264

Chen X, Zhang X, Wan J, Wang Z, Qian Y (2005) Selective fabrication of metastable greigite $\left(\mathrm{Fe}_{3} \mathrm{~S}_{4}\right)$ nanocrystallites and its magnetic properties through a simple solution-based route. Chem Phys Lett 403: 396-399

Cody GD (2005) Geochemical connections to primitive metabolism. Elements 1:139-143

Cody GD, Boctor NZ, Brandes JA, Filley TR, Hazen RM, Yoder HS (2004) Assaying the catalytic potential of transition metal sulfides for abiotic carbon fixation. Geochim Cosmochim Acta 68:2185-2196

Cody GD, Boctor NZ, Hazen RM, Brandes JA, Morowitz HJ, Yoder HS (2001) Geochemical roots of autotrophic carbon fixation: Hydrothermal experiments in the system citric acid, $\mathrm{H}_{2} \mathrm{O}-( \pm \mathrm{FeS})-( \pm \mathrm{NiS})$. Geochim Cosmochim Acta 65:3557-3576

Corliss JB, Baross JA, Hoffman SE (1981) An hypothesis concerning the relationship between submarine hot springs and the origin of life on Earth. Oceanol Acta Suppl 4:59-69

Davis BS (1997) Geomicrobiology of the oxic zone of sulfidic mine tailings. In: Biological-mineralogical interactions. McIntosh JM, Groat LA (eds) Mineralogical Association of Canada, Ottawa, p 93-112

Dekkers MJ, Passier HF, Schoonen MAA (2000) Magnetic properties of hydrothermally synthesized greigite $\left(\mathrm{Fe}_{3} \mathrm{~S}_{4}\right)$ - II. High- and low-temperature characteristics. Geophys J Int 141:809-819

DeLong EF, Frankel RB, Bazylinski DA (1993) Multiple evolutionary origins of magnetotaxis in bacteria. Science 259:803-806

Desbruyeres D, Chevaldonne P, Alayse AM, Jollivet D, Lallier FH, Jouin-Toulmond C, Zal F, Sarradin PM, Cosson R, Caprais JC, Arndt C, O'Brien J, Guezennec J, Hourdez S, Riso R, Gaill F, Laubier L, Toulmond A (1998) Biology and ecology of the "Pompeii worm" (Alvinella pompejana Desbruyeres and Laubier), a normal dweller of an extreme deep-sea environment: A synthesis of current knowledge and recent developments. Deep-Sea Res II 45:383-422

Diaz-Ricci JC, Kirschvink JL (1992) Magnetic domain state and coercivity predictions for biogenic greigite $\left(\mathrm{Fe}_{3} \mathrm{~S}_{4}\right)$ : A comparison of theory with magnetosome observations. J Geophys Res 97:17309-17315

Diebel CE, Proksch R, Green CR, Neilson P, Walker MM (2000) Magnetite defines a vertebrate magnetoreceptor. Nature 406:299-302

Dobson J (2001) Nanoscale biogenic iron oxides and neurodegenerative disease. FEBS Lett 496:1-5

Donald R, Southam G (1999) Low temperature anaerobic bacterial diagenesis of ferrous monosulfide to pyrite. Geochim Cosmochim Acta 63:2019-2023

Dove PM, De Yoreo JJ, Weiner S (eds) (2003) Biomineralization. Rev Mineral Geochem 54. Mineralogical Society of America

Dunin-Borkowski RE, McCartney MR, Frankel RB, Bazylinski DA, Pósfai M, Buseck PR (1998) Magnetic microstructure of magnetotactic bacteria by electron holography. Science 282:1868-1870

Dunin-Borkowski RE, McCartney MR, Pósfai M, Frankel RB, Bazylinski DA, Buseck PR (2001) Off-axis electron holography of magnetotactic bacteria: Magnetic microstructure of strains MV-1 and MS-1. Eur J Mineral 13:671-684

Dunin-Borkowski RE, McCartney MR, Smith DJ (2004) Electron holography of nanostructured materials. In: Encyclopedia of Nanoscience and Nanotechnology. Nalwa HS (ed) American Scientific Pubs., p 41-100

Dunlop DJ, Özdemir Ö (1997) Rock Magnetism: Fundamentals and Frontiers. Cambridge University Press

Edwards KJ, Bach W, McCollom TM (2005) Geomicrobiology in oceanography: Microbe-mineral interactions at and below the seafloor. Trends Microbiol 13:449-456

Edwards KJ, Bond PL, Druschel GK, McGuire MM, Hamers RJ, Banfield JF (2000) Geochemical and biological aspects of sulfide mineral dissolution: Lessons from Iron Mountain, California. Chem Geol 169:383-397 
Edwards KJ, Hu B, Hamers RJ, Banfield JF (2001) A new look at microbial leaching patterns on sulfide minerals. FEMS Microbiol Ecol 34:197-206

Edwards KJ, McCollom TM, Konishi H, Buseck PR (2003) Seafloor bioalteration of sulfide minerals: Results from in situ incubation studies. Geochim Cosmochim Acta 67:2843-2856

Farina M, Esquivel DMS, Lins de Barros HGP (1990) Magnetic iron-sulphur crystals from a magnetotactic microorganism. Nature 343:256-258

Ferris FG (1997) Formation of authigenic minerals by bacteria. In: Biological-mineralogical interactions. McIntosh JM, Groat LA (eds) Mineralogical Association of Canada, Ottawa, p 187-208

Ferris FG, Fyfe WS, Beveridge TJ (1987) Bacteria as nucleation sites for authigenic minerals in a metalcontaminated lake sediment. Chem Geol 63:225-232

Flies CB, Jonkers HM, de Beer D, Bosselmann K, Bottcher ME, Schüler D (2005) Diversity and vertical distribution of magnetotactic bacteria along chemical gradients in freshwater microcosms. FEMS Microbiol Ecol 52:185-195

Fortin D, Beveridge TJ (1997) Microbial sulfate reduction within sulfidic mine tailings: Formation of diagenetic Fe sulfides. Geomicrobiol J 14:1-21

Fortin D, Ferris FG, Beveridge TJ (1997) Surface-mediated mineral development by bacteria. Rev Mineral 35: $161-180$

Fortin D, Langley S (2005) Formation and occurrence of iron-rich biogenic minerals. Earth-Sci Rev 72:1-19

Fortin D, Rioux J-P, Roy M (2002) Geochemistry of iron and sulfur in the zone of microbial sulfate reduction in mine tailings. Water Air Soil Pollution 2:37-56

Frankel RB (1984) Magnetic guidance of organisms. Annu Rev Biophys Bioeng 13:85-103

Frankel RB, Bazylinski DA (2003) Biologically induced mineralization by bacteria. Rev Mineral Geochem 54: 95-114

Frankel RB, Bazylinski DA, Johnson MS, Taylor BL (1997) Magneto-aerotaxis in marine coccoid bacteria. Biophys J 73:994-1000

Fukumori Y (2000) Enzymes for magnetite synthesis in Magnetospirillum magnetotacticum. In: Biomineralization. Baeuerlein E (ed) Wiley, p 93-108

Furukawa Y, Barnes HL (1995) Reactions forming pyrite from precipitated amorphous ferrous sulfide. In: Geochemical transformations of sedimentary sulfur. Vairavamurthy MA, Schoonen MAA (eds) American Chemical Society, p 194-205

Gilbert PUPA, Abrecht M, Frazer BH (2005) The organic-mineral interface in biominerals. Rev Mineral Geochem 59:157-185

Goffredi SK, Warén A, Orphan VJ, Van Dover CL, Vrijenhoek RC (2004) Novel forms of structural integration between microbes and a hydrothermal vent gastropod from the Indian Ocean. Appl Environ Microbiol 70: 3082-3090

Gould WD, Francis M, Blowes DW, Krouse HR (1997) Biomineralization: Microbiological formation of sulfide minerals. In: Biological-mineralogical interactions. McIntosh JM, Groat LA (eds) Mineralogical Association of Canada, $\mathrm{p}$ 169-186

Grimes ST, Brock F, Rickard D, Davies KL, Edwards D, Briggs DEG, Parkes RJ (2001) Understanding fossilization: Experimental pyritization of plants. Geology 29:123-126

Hackl RP (1997) Commercial applications of bacteria-mineral interactions. In: Biological-mineralogical interactions. McIntosh JM, Groat LA (eds) Mineralogical Association of Canada, Ottawa, p 143-167

Hámor T (1994) The occurrence and morphology of sedimentary pyrite. Acta Geol Hung 37:153-181

Herbert RB Jr., Benner SG, Pratt AR, Blowes DW (1998) Surface chemistry and morphology of poorly crystalline iron sulfides precipitated in media containing sulfate-reducing bacteria. Chem Geol 144:87-97

Heywood BR, Bazylinski DA, Garratt-Reed A, Mann S, Frankel RB (1990) Controlled biosynthesis of greigite $\left(\mathrm{Fe}_{3} \mathrm{~S}_{4}\right)$ in magnetotactic bacteria. Naturwiss 77:536-538

Heywood BR, Mann S, Frankel RB (1991) Structure, morphology and growth of biogenic greigite $\left(\mathrm{Fe}_{3} \mathrm{~S}_{4}\right)$. Mat Res Soc Symp Proc 218:93-108

Hoffmann V (1992) Greigite $\left(\mathrm{Fe}_{3} \mathrm{~S}_{4}\right)$ : Magnetic properties and first domain observations. Phys Earth Planet Int 70:288-301

Holmes J (1999) Fate of incorporated metals during mackinawite oxidation in sea water. Appl Geochem 14: 277-281

Horiuchi S (1971) Zur Umwandlung von Mackinawit $(\mathrm{FeS})$ in Greigit $\left(\mathrm{Fe}_{3} \mathrm{~S}_{4}\right)$ durch Elektronenstrahlen. Z Anorg Allg Chem 386:208-212

Huber C, Wächtershäuser G (1997) Activated acetic acid by carbon fixation on (Fe,Ni)S under primordial conditions. Science 276:245-247

Huber JA, Butterfield DA, Baross JA (2003) Bacterial diversity in a subseafloor habitat following a deep-sea volcanic eruption. FEMS Microbiol Ecol 43:393-409

Hurtgen MT, Lyons TW, Ingall ED, Cruse AM (1999) Anomalous enrichments of iron monosulfide in euxinic marine sediments and the role of $\mathrm{H}_{2} \mathrm{~S}$ in iron sulfide transformations: Examples from Effingham Inlet, Orca Basin, and the Black Sea. Am J Sci 299:556-588 
Jambor JL, Blowes DW, Ptacek CJ (2000) Mineralogy of mine wastes and strategies of remediation. In: Environmental Mineralogy. Vaughan DJ, Wogelius RA (eds) EMU Notes in Mineralogy 2, Eötvös University Press, p 255-290

Jannasch HW, Mottl MJ (1985) Geomicrobiology of deep-sea hydrothermal vents. Science 229:717-725

Jørgensen BB (1977) Sulfur cycle of a coastal marine sediment (Limfjorden, Denmark). Limnol Oceanogr 22: 814-832

Kappler A, Straub KL (2005) Geomicrobiological cycling of iron. Rev Mineral Geochem 59:85-108

Kasama T, Pósfai M, Chong RKK, Finlayson AP, Buseck PR, Frankel RB, Dunin-Borkowski RE (2006) Magnetic properties, microstructure, composition and morphology of greigite nanocrystals in magnetotactic bacteria from electron holography and tomography. Am Mineral (in press)

Kaschke M, Russell MJ, Cole WJ (1994) $\mathrm{FeS} / \mathrm{FeS}_{2}$ - a redox system for the origin of life - (some experiments on the pyrite-hypothesis). Orig Life Evol Biosph 24:43-56

Keim CN, Abreu F, Lins U, de Barros HL, Farina M (2004) Cell organization and ultrastructure of a magnetotactic multicellular organism. J Struct Biol 145:254-262

Kirschvink JL, Hagadorn JW (2000) A grand unified theory of biomineralization. In: Biomineralization. Baeuerlein E (ed) Wiley, p 139-150

Kirschvink JL, Kobayashi-Kirschvink A, Woodford BJ (1992) Magnetite biomineralization in the human brain Proc Natl Acad Sci USA 89:7683-7687

Kirschvink JL, Walker MM, Diebel CE (2001) Magnetite-based magnetoreception. Curr Opin Neurobiol 11: 462-467

Komeili A, Li Z, Newman DK, Jensen GJ (2006) Magnetosomes are cell membrane invaginations organized by the actin-like protein MamK. Science 311:242-245

Komeili A, Vali H, Beveridge TJ, Newman DK (2004) Magnetosome vesicles are present before magnetite formation, and MamA is required for their activation. Proc Natl Acad Sci USA 101:3839-3844

Konhauser KO (1998) Diversity of bacterial iron mineralization. Earth-Sci Rev 43:91-121

Kuenen JG, Robertson LA, Tuovinen OH (1992) The genera Thiobacillus, Thiomicrospira, and Thiosphera. In: The Prokaryotes. Balows A, Truper HG, Dworkin M, Harder W, Schleifer KH (eds) Springer, p 26382657

Labrenz M, Druschel GK, Thomsen-Ebert T, Gilbert B, Welch SA, Kemner KM, Logan GA, Summons RE, De Stasio G, Bond PL, Lai B, Kelly SD, Banfield JF (2000) Formation of sphalerite (ZnS) deposits in natural biofilms of sulfate-reducing bacteria. Science 290:1744-1747

Lennie AR, Redfern SAT, Champness PE, Stoddart CP, Schofield PF, Vaughan DJ (1997) Transformation of mackinawite to greigite: An in situ X-ray powder diffraction and transmission electron microscope study. Am Mineral 82:302-309

Lennie AR, Vaughan DJ (1996) Spectroscopic studies of iron sulfide formation and phase relations at low temperatures. Mineral Spectr 5:117-131

Lins U, Farina M (1999) Organization of cells in magnetotactic multicellular aggregates. Microbiol Res 154 9-13

Lins U, Farina M (2001) Amorphous mineral phases in magnetotactic multicellular aggregates. Arch Microbiol $176: 323-328$

Lovley DR (2003) Cleaning up with genomics: Applying molecular biology to bioremediation. Nature Rev Microbiol 1:35-44

Lovley DR, Chapelle FH (1995) Deep subsurface microbial processes. Rev Geophys 33:365-381

Lowenstam HA, Weiner S (1989) On Biomineralization. Oxford University Press

Luther GW (1991) Pyrite synthesis via polysulfide compounds. Geochim Cosmochim Acta 55:2839-2849

Luther GW, Rickard D (2005) Metal sulfide cluster complexes and their biogeochemical importance in the environment. J Nanoparticle Res 7:389-407

Luther GW, Rozan TF, Taillefert M, Nuzzio DB, Di Meo C, Shank TM, Lutz RA, Cary SC (2001) Chemical speciation drives hydrothermal vent ecology. Nature 410:813-816

Lysnes K, Thorseth IH, Steinsbu BO, Ovreas L, Torsvik T, Pedersen RB (2004) Microbial community diversity in seafloor basalt from the Arctic spreading ridges. 50:213-230

Maginn EJ, Little CTS, Herrington RJ, Mills RA (2002) Sulphide mineralisation in the deep sea, hydrothermal vent polychaete, Alvinella pompejana: implications for fossil preservation. Mar Geol 181:337-356

Mann S (1997) Biomimetic Materials Chemistry. Wiley-VCH

Mann S (2001) Biomineralization: Principles and Concepts in Bioinorganic Materials Chemistry. Oxford University Press

Mann S, Sparks NHC, Frankel RB, Bazylinski DA, Jannasch HW (1990) Biomineralization of ferrimagnetic greigite $\left(\mathrm{Fe}_{3} \mathrm{~S}_{4}\right)$ and iron pyrite $\left(\mathrm{FeS}_{2}\right)$ in a magnetotactic bacterium. Nature 343:258-261

McCartney MR, Lins U, Farina M, Buseck PR, Frankel RB (2001) Magnetic microstructure of bacterial magnetite by electron holography. Eur J Mineral 13:685-689

McIntosh JM, Groat LA (1997) Biological-mineralogical interactions. Mineralogical Association of Canada 
McIntosh JM, Silver M, Groat LA (1997) Bacteria and the breakdown of sulfide minerals. In: Biologicalmineralogical interactions. McIntosh JM, Groat LA (eds) Mineralogical Association of Canada, Ottawa, p 63-92

Meldrum FC, Wade VJ, Nimmo DL, Heywood BR, Mann S (1991) Synthesis of inorganic nanophase materials in supramolecular protein cages. Nature 349:684-687

Methe BA, Nelson KE, Eisen JA, Paulsen IT, Nelson W, Heidelberg JF, Wu D, Wu M, Ward N, Beanan MJ, Dodson RJ, Madupu R, Brinkac LM, Daugherty SC, DeBoy RT, Durkin AS, Gwinn M, Kolonay JF, Sullivan SA, Haft DH, Selengut J, Davidsen TM, Zafar N, White O, Tran B, Romero C, Forberger HA, Weidman J, Khouri H, Feldblyum TV, Utterback TR, Van Aken SE, Lovley DR, Fraser CM (2003) Genome of Geobacter sulfurreducens: Metal reduction in subsurface environments. Science 302:1967-1969

Moreau JW, Webb RI, Banfield JF (2004) Ultrastructure, aggregation-state, and crystal growth of biogenic nanocrystalline sphalerite and wurtzite. Am Mineral 89:950-960

Morse JW, Millero FJ, Cornwell JC, Rickard D (1987) The chemistry of the hydrogen sulfide and iron sulfide systems in natural waters. Earth-Sci Rev 24:1-42

Murowchick JB, Barnes HL (1986) Marcasite precipitation from hydrothermal solutions. Geochim Cosmochim Acta 50:2615-2629

Nagaoka T, Ohmura N, Saiki H (1999) A novel mineral flotation process using Thiobacillus ferrooxidans. Appl Environ Microbiol 65:3588-3593

Neal AL, Techkarnjanaruk S, Dohnalkova A, McCready D, Peyton BM, Geesey GG (2001) Iron sulfides and sulfur species produced at hematite surfaces in the presence of sulfate-reducing bacteria. Geochim Cosmochim Acta 65:223-235

Nealson KH, Saffarini D (1994) Iron and manganese in anaerobic respiration. Annu Rev Microbiol 48:311-343

Nealson KH, Stahl DA (1997) Microorganisms and biogeochemical cycles: What can we learn from layered microbial communities? Rev Mineral 35:5-34

Nemati M, Harrison STL, Hansford GS, Webb C (1998) Biological oxidation of ferrous sulphate by Thiobacillus ferrooxidans: a review on the kinetic aspects. Biochem Eng J 1:171-190

Nordstrom DK, Southam G (1997) Geomicrobiology of sulfide mineral oxidation. Rev Mineral 35:361-390

Ohfuji H, Akai J (2002) Icosahedral domain structure of framboidal pyrite. Am Mineral 87:176-180

Ohfuji H, Boyle AP, Prior DJ, Rickard D (2005) Structure of framboidal pyrite: An electron backscatter diffraction study. Am Mineral 90:1693-1704

Ohfuji H, Rickard D (2005) Experimental syntheses of framboids - a review. Earth-Sci Rev 71:147-170

Ohfuji H, Rickard D (2006) High resolution transmission electron microscopic study of synthetic nanocrystalline mackinawite. Earth Planet Sci Lett 241:227-233

Olson GJ (1991) Rate of pyrite bioleaching by Thiobacillus ferrooxidans - results of an interlaboratory comparison. Appl Environ Microbiol 57:642-644

Paktunc AD, Dave NK (2002) Formation of secondary pyrite and carbonate minerals in the Lower Williams Lake tailings basin, Elliot Lake, Ontario, Canada. Am Mineral 87:593-602

Pearce CI, Pattrick RAD, Vaughan DJ (2006) Electrical and Magnetic properties of sulfides. Rev Mineral Geochem 61:127-180

Pina PS, Leao VA, Silva CA, Daman D, Frenay J (2005) The effect of ferrous and ferric iron on sphalerite bioleaching with Acidithiobacillus sp. Mineral Eng 18:549-551

Pósfai M, Buseck PR, Bazylinski DA, Frankel RB (1998a) Iron sulfides from magnetotactic bacteria: Structure, composition, and phase transitions. Am Mineral 83:1469-1481

Pósfai M, Buseck PR, Bazylinski DA, Frankel RB (1998b) Reaction sequence of iron sulfide minerals in bacteria and their use as biomarkers. Science 280:880-883

Pósfai M, Cziner K, Márton E, Márton P, Buseck PR, Frankel RB, Bazylinski DA (2001) Crystal-size distributions and possible biogenic origin of Fe sulfides. Eur J Mineral 13:691-703

Poulton SW, Fralick PW, Canfield DE (2004) The transition to a sulphidic ocean $\sim 1.84$ billion years ago. Nature 431:173-177

Raiswell R, Canfield DE (1998) Sources of iron for pyrite formation in marine sediments. Am J Sci 298:219245

Raiswell R, Whaler K, Dean S, Coleman ML, Briggs DEG (1993) A simple 3-dimensional model of diffusionwith-precipitation applied to localized pyrite formation in framboids, fossils and detrital iron minerals. Mar Geol 113:89-100

Rawlings DE, Silver S (1995) Mining with microbes. Bio-Technol 13:773-778

Reynolds RL, Tuttle ML, Rice CA, Fishman NS, Karachewski JA, Sherman DM (1994) Magnetization and geochemistry of greigite-bearing Cretaceous strata, North-Slope Basin, Alaska. Am J Sci 294:485-528

Rickard D (1997) Kinetics of pyrite formation by the $\mathrm{H}_{2} \mathrm{~S}$ oxidation of iron (II) monosulfide in aqueous solutions between 25 and 125 degrees C: The rate equation. Geochim Cosmochim Acta 61:115-134

Rickard D, Butler IB, Oldroyd A (2001) A novel iron sulphide mineral switch and its implications for Earth and planetary science. Earth Planet Sci Lett 189:85-91

Rickard D, Luther GW (2006) Metal sulfide complexes and clusters. Rev Mineral Geochem XX 
Rickard D, Morse JW (2005) Acid volatile sulfide (AVS). Mar Chem 97:141-197

Rickard D, Schoonen MAA, Luther GW (1995) Chemistry of iron sulfides in sedimentary environments. In: Geochemical Transformations of Sedimentary Sulfur. ACS Symposium Series 612, p 168-193

Roberts AP (1995) Magnetic properties of sedimentary greigite $\left(\mathrm{Fe}_{3} \mathrm{~S}_{4}\right)$. Earth Planet Sci Lett 134:227-236

Rodgers FG, Blakemore RP, Blakemore NA, Frankel RB, Bazylinski DA, Maratea D, Rodgers C (1990) Intercellular structure in a many-celled magnetotactic prokaryote. Arch Microbiol 154:18-22

Rosso KM, Vaughan DJ (2006) Reactivity of sulfide mineral surfaces. Rev Mineral Geochem 61:557-607

Rowan CJ, Roberts AP (2006) Magnetite dissolution, diachronous greigite formation, and secondary magnetizations from pyrite oxidation: Unravelling complex magnetizations in Neogene marine sediments from New Zealand. Earth Planet Sci Lett 241:119-137

Russell MJ, Daia DE, Hall AJ (1998) The emergence of life from FeS bubbles at alkaline hot springs in an acid ocean. In: Thermophiles: The Keys to Molecular Evolution and the Origin of Life. Adams MWW, Ljungdahl LG, Wiegel J (eds) Taylor and Francis, p 77-121

Russell MJ, Hall AJ (1997) The emergence of life from iron monosulphide bubbles at a submarine hydrothermal redox and $\mathrm{pH}$ front. J Geol Soc 154:377-402

Scheffel A, Gruska M, Faivre D, Linaroudis A, Plitzko JM, Schüler D (2005) An acidic protein aligns magnetosomes along a filamentous structure in magnetotactic bacteria. Nature AOP:DOI 10.1038/ nature 04382

Schippers A, Jørgensen BB (2002) Biogeochemistry of pyrite and iron sulfide oxidation in marine sediments. Geochim Cosmochim Acta 66:85-92

Schoonen M, Smirnov A, Cohn C (2004) A perspective on the role of minerals in prebiotic synthesis. Ambio 33:539-551

Schoonen MAA (2004) Mechanisms of sedimentary pyrite formation. In: Sulfur Biogeochemistry - Past and present Geological Society of America Special Paper. Amend JP, Edwards KJ, Lyons TW (eds) Geological Society of America, p 117-134

Schoonen MAA, Barnes HL (1991) Reactions forming pyrite and marcasite from solution: I. Nucleation of $\mathrm{FeS}_{2}$ below $100{ }^{\circ} \mathrm{C}$. Geochim Cosmochim Acta 55:1495-1504

Schoonen MAA, Xu Y, Bebie J (1999) Energetics and kinetics of the prebiotic synthesis of simple organic acids and amino acids with the $\mathrm{FeS}-\mathrm{H}_{2} \mathrm{~S} / \mathrm{FeS}_{2}$ redox couple as reductant. Orig Life Evol Biosph 29:5-32

Schrenk MO, Kelley DS, Delaney JR, Baross JA (2003) Incidence and diversity of microorganisms within the walls of an active deep-sea sulfide chimney. Appl Environ Microbiol 69:3580-3592

Schultze-Lam S, Fortin D, Davis BS, Beveridge TJ (1996) Mineralization of bacterial surfaces. Chem Geol 132: $171-181$

Schüler D (2004) Molecular analysis of a subcellular compartment: The magnetosome membrane of Magnetospirillum gryphiswaldense. Arch Microbiol 181:1-7

Schüler DR, Uhl E, Baeuerlein E (1995) A simple light scattering method to assay magnetism in Magnetospirillum gryphiswaldense. FEMS Microbiol Lett 132:139-145

Scott SD, Barnes HL (1972) Sphalerite-wurtzite equilibria and stoichiometry. Geochim Cosmochim Acta 36: 1275-1295

Shenton W, Pum D, Sleytr UB, Mann S (1997) Synthesis of cadmium sulphide superlattices using selfassembled bacterial S-layers. Nature 389:585-587

Shock EL (1992) Chemical environments of submarine hydrothermal systems. Orig Life Evol Biosph 22:67107

Simmons SL, Bazylinski DA, Edwards KJ (2006) South-seeking magnetotactic bacteria in the Northern Hemisphere. Science 311:371-374

Simmons SL, Sievert SM, Frankel RB, Bazylinski DA, Edwards KJ (2004) Spatiotemporal distribution of marine magnetotactic bacteria in a seasonally stratified coastal salt pond. Appl Environ Microbiol 70: 6230-6239

Simpson ET, Kasama T, Pósfai M, Buseck PR, Harrison RJ, Dunin-Borkowski RE (2005a) Magnetic induction mapping of magnetite chains in magnetotactic bacteria at room temperature and close to the Verwey transition using electron holography. J Phys Conf Ser 17:108-121

Simpson SL, Apte SC, Davies CM (2005b) Bacterially assisted oxidation of copper sulfide minerals in tropical river waters. Environ Chem 2:49-55

Stanjek H, Fassbinder JWE, Vali H, Wägele H, Graf W (1994) Evidence of biogenic greigite (ferrimagnetic $\mathrm{Fe}_{3} \mathrm{~S}_{4}$ ) in soil. Eur J Soil Sci 45:97-103

Summit M, Baross JA (2001) A novel microbial habitat in the mid-ocean ridge subseafloor. Proc Natl Acad Sci USA 98:2158-2163

Suzuki Y, Inagaki F, Takai K, Nealson KH, Horikoshi K (2004) Microbial diversity in inactive chimney structures from deep-sea hydrothermal systems. Microbial Ecol 47:186-196 
Suzuki Y, Kopp RE, Kogure T, Suga A, Takai K, Tsuchida S, Ozaki N, Endo K, Hashimoto J, Kato Y, Mizota C, Hirata T, Chiba H, Nealson KH, Horikoshi K, Kirschvink JL (2006) Sclerite formation in the hydrothermalvent "scaly-foot" gastropod - possible control of iron sulfide biomineralization by the animal. Earth Planet Sci Lett 242:39-50

Sweeney RE, Kaplan IR (1973) Pyrite framboid formation: Laboratory synthesis and marine sediments. Geology 68:618-634

Thamdrup B, Fossing H, Jørgensen BB (1994) Manganese, iron, and sulfur cycling in a coastal marine sediment, Aarhus Bay, Denmark. Geochim Cosmochim Acta 58:5115-5129

Theberge SM, Luther GW, Farrenkopf AM (1997) On the existence of free and metal complexed sulfide in the Arabian Sea and its oxygen minimum zone. Deep-Sea Res 44:1381-1390

Thorseth IH, Torsvik T, Torsvik V, Daae FL, Pedersen RB (2001) Diversity of life in ocean floor basalt. Earth Planet Sci Lett 194:31-37

Tuttle JH, Dugan PR, MacMillan CB, Randles CI (1969) Microbial dissimilatory sulfur cycle in acid mine water. J Bacteriol 97:594-602

Van Dover CL, Humphris SE, Fornari D, Cavanaugh CM, Collier R, Goffredi SK, Hashimoto J, Lilley MD, Reysenbach AL, Shank TM, Von Damm KL, Banta A, Gallant RM, Gotz D, Green D, Hall J, Harmer TL, Hurtado LA, Johnson P, McKiness ZP, Meredith C, Olson E, Pan IL, Turnipseed M, Won Y, Young CR, Vrijenhoek RC (2001) Biogeography and ecological setting of Indian Ocean hydrothermal vents. Science 294:818-823

Vaughan DJ, Wogelius RA (2000) Environmental Mineralogy. EMU Notes in Mineralogy 2. Eötvös University Press

Verati C, de Donato P, Prieur D, Lancelot J (1999) Evidence of bacterial activity from micrometer-scale layer analyses of black-smoker sulfide structures (Pito Seamount Site, Easter microplate). Chem Geol 158: 257-269

Wächtershäuser G (1990) Evolution of the first metabolic cycles. Proc Natl Acad Sci USA 87:200-204

Wächtershäuser G (1988) Pyrite formation, the first energy source for life: A hypothesis. System Appl Microbiol 10:207-210

Walker MM, Dennis TE, Kirschvink JL (2002) The magnetic sense and its use in long-distance navigation by animals. Curr Opin Neurobiol 12:735-744

Warén A, Bengtson S, Goffredi SK, Van Dover CL (2003) A hot-vent gastropod with iron sulfide dermal sclerites. Science 302:1007-1007

Watson JHP, Cressey BA, Roberts AP, Ellwood DC, Charnock JM, Soper AK (2000) Structural and magnetic studies on heavy-metal-adsorbing iron sulphide nanoparticles produced by sulphate-reducing bacteria. J Magn Magn Mat 214:13-30

Watson JHP, Ellwood DC (1994) Biomagnetic separation and extraction process for heavy-metals from solution. 7:1017-1028

Weiner S, Dove PM (2003) An overview of biomineralization processes and the problem of the vital effect. Rev Mineral Geochem 54:1-29

Wilkin RT, Barnes HL (1997) Formation processes of framboidal pyrite. Geochim Cosmochim Acta 61:323339

Wilkin RT, Barnes HL, Brantley SL (1996) The size distribution of framboidal pyrite in modern sediments: An indicator of redox conditions. Geochim Cosmochim Acta 60:3897-3912

Wiltschko R, Wiltschko W (1995) Magnetic orientation in animals. Springer

Winklhofer M, Holtkamp-Rötzler E, Hanzlik M, Fleissner G, Petersen N (2001) Clusters of superparamagnetic magnetite particles in the upper-beak skin of homing pigeons: Evidence of a magnetoreceptor? Eur J Mineral 13:659-670

Wolthers M, Van der Gaast SJ, Rickard D (2003) The structure of disordered mackinawite. Am Mineral 88: 2007-2015

Wong KKW, Mann S (1996) Biomimetic synthesis of cadmium sulfide-ferritin nanocomposites. Adv Mater 8: 928-931

Zbinden M, Le Bris N, Compere P, Martinez I, Guyot F, Gaill F (2003) Mineralogical gradients associated with alvinellids at deep-sea hydrothermal vents. Deep-Sea Res 50:269-280

Zbinden M, Martinez I, Guyot F, Cambon-Bonavita MA, Gaill F (2001) Zinc-iron sulphide mineralization in tubes of hydrothermal vent worms. Eur J Mineral 13:653-659

Zhang HZ, Huang F, Gilbert B, Banfield JF (2003) Molecular dynamics simulations, thermodynamic analysis, and experimental study of phase stability of zinc sulfide nanoparticles. J Phys Chem B 107:1305113060 